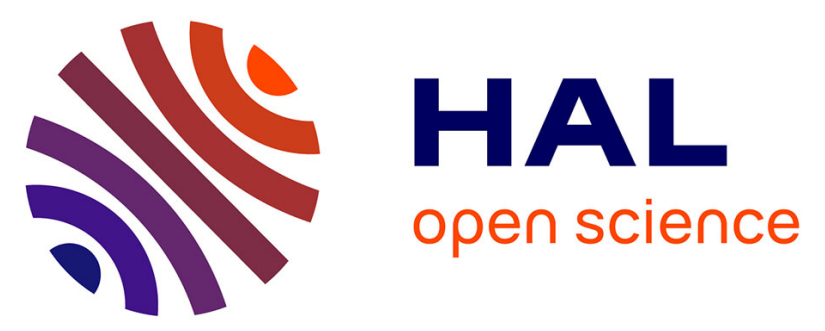

\title{
Mechanisms of angiotensin II-mediated activation of aldosterone synthase in H295R human adrenocortical and rat adrenal glomerulosa cells
}

Mária Szekeres, Gábor Turu, Anna Orient, Bence Szalai, Katinka Süpeki, Miklós Cserzö, Péter Várnai, László Hunyady

\section{To cite this version:}

Mária Szekeres, Gábor Turu, Anna Orient, Bence Szalai, Katinka Süpeki, et al.. Mechanisms of angiotensin II-mediated activation of aldosterone synthase in H295R human adrenocortical and rat adrenal glomerulosa cells. Molecular and Cellular Endocrinology, 2009, 302 (2), pp.244. 10.1016/j.mce.2008.12.015 . hal-00499108

\section{HAL Id: hal-00499108 https://hal.science/hal-00499108}

Submitted on 9 Jul 2010

HAL is a multi-disciplinary open access archive for the deposit and dissemination of scientific research documents, whether they are published or not. The documents may come from teaching and research institutions in France or abroad, or from public or private research centers.
L'archive ouverte pluridisciplinaire HAL, est destinée au dépôt et à la diffusion de documents scientifiques de niveau recherche, publiés ou non, émanant des établissements d'enseignement et de recherche français ou étrangers, des laboratoires publics ou privés. 


\section{Accepted Manuscript}

Title: Mechanisms of angiotensin II-mediated activation of aldosterone synthase in H295R human adrenocortical and rat adrenal glomerulosa cells

Authors: Mária Szekeres, Gábor Turu, Anna Orient, Bence Szalai, Katinka Süpeki, Miklós Cserző, Péter Várnai, László

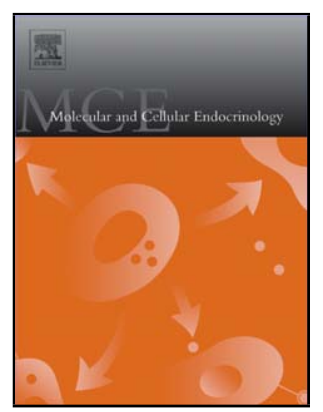
Hunyady

PII: S0303-7207(09)00028-8

DOI: doi:10.1016/j.mce.2008.12.015

Reference: MCE 7113

To appear in: $\quad$ Molecular and Cellular Endocrinology

Received date: $\quad 22-9-2008$

Revised date: $\quad 23-12-2008$

Accepted date: $\quad 31-12-2008$

Please cite this article as: Szekeres, M., Turu, G., Orient, A., Szalai, B., Süpeki, K., Cserző, M., Várnai, P., Hunyady, L., Mechanisms of angiotensin II-mediated activation of aldosterone synthase in H295R human adrenocortical and rat adrenal glomerulosa cells, Molecular and Cellular Endocrinology (2008), doi:10.1016/j.mce.2008.12.015

This is a PDF file of an unedited manuscript that has been accepted for publication. As a service to our customers we are providing this early version of the manuscript. The manuscript will undergo copyediting, typesetting, and review of the resulting proof before it is published in its final form. Please note that during the production process errors may be discovered which could affect the content, and all legal disclaimers that apply to the journal pertain. 


\section{Mechanisms of angiotensin II-mediated activation of aldosterone synthase in H295R} human adrenocortical and rat adrenal glomerulosa cells

Mária Szekeres*, Gábor Turu, Anna Orient, Bence Szalai, Katinka Süpeki, Miklós Cserző, Péter Várnai, László Hunyady

Department of Physiology, Semmelweis University, Faculty of Medicine, Budapest, Hungary and Laboratory of Neurobiochemistry and Molecular Physiology, Semmelweis University and Hungarian Academy of Sciences, Budapest, Hungary

*Corresponding author.

Address: P.O.Box 259, H-1444 Budapest, Hungary

Phone: +36-1-4191500 / 60451

Fax: +36-1-266-6504

Email address: szekeres@eok.sote.hu 


\begin{abstract}
In adrenal zona glomerulosa cells angiotensin II (Ang II) is a key regulator of steroidogenesis. Our purpose was to compare the mechanisms of Ang II-induced changes in the expression level of early transcription factors NR4A1 (NGFIB) and NR4A2 (Nurr1) genes, and the CYP11B2 gene encoding aldosterone synthase in H295R human adrenocortical tumor cells and in primary rat adrenal glomerulosa cells. Real-time PCR studies have demonstrated that Ang II increased the expression levels of NR4A1 and NR4A2 in H295R cells within one hour after stimulation, which persisted up to $6 \mathrm{hrs}$; whereas in rat adrenal glomerulosa cells the kinetics of the expression of these genes were more rapid and transient. Ang II also induced prolonged nuclear translocation of Nurr1 and NGFIB proteins in both cell types. Studies using MEK inhibitor (PD98059,

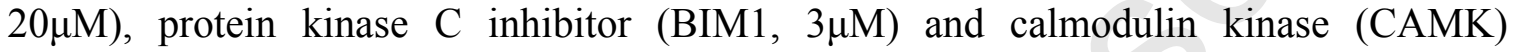
inhibitor $(\mathrm{KN} 93,10 \mu \mathrm{M})$ revealed that in rat adrenal glomerulosa cells CAMK-mediated mechanisms play a predominant role in the regulation of CYP11B2. In accordance with earlier findings, in H295R cells MEK inhibition increased the expression of NR4A1, NR4A2 and CYP11B2 genes, however, it decreased the Ang II-induced gene expression levels, suggesting that ERK activation has a role in control of expression of these genes. No such mechanism was detected in rat glomerulosa cells. Sar $^{1}-$ Ile $^{4}$-Ile ${ }^{8}$-AngII, which can cause $\mathrm{G}$ protein-independent ERK activation, also stimulated the expression of CYP11B2 in H295R cells. These data suggest that the previously reported CAMKmediated stimulation of early transcription factors NGFIB and Nurr1 has a predominant role in Ang II-induced CYP11B2 activation in rat adrenal glomerulosa cells, whereas in $\mathrm{H} 295 \mathrm{R}$ cells ERK activation and G protein-independent mechanisms also contribute to this process.
\end{abstract}

Keywords: adrenal cortex, aldosterone synthase, angiotensin II, calmodulin kinase, gene expression,

Short title: Ang II-mediated gene induction in adrenocortical cells

\title{
1. Introduction
}

Angiotensin II (Ang II) is the major effector molecule of the renin-angiotensin system, which has major physiological and pathophysiological roles in different cell types and organs, such as regulation of vasoconstriction, aldosterone secretion, cell growth, proliferation, differentiation and tissue remodeling, inflammation, atherosclerosis, diabetic nephropathy and cancer. Ang II exerts its actions via $\mathrm{AT}_{1}$ and $\mathrm{AT}_{2}$ angiotensin receptors. Ang II-induced $\mathrm{AT}_{1}$ receptor activation stimulates $\mathrm{G}$ proteindependent and -independent mechanisms, as well (de Gasparo et al., 2000; Hunyady and Catt, 2006; Oliveira et al., 2007). $\mathrm{AT}_{1}$ receptor activation via $\mathrm{G}_{\mathrm{q} / 11}$ protein stimulates phospholipases, $\mathrm{IP}_{3} / \mathrm{DAG}$ signaling, protein kinase $\mathrm{C}$ (PKC), phosphoinositide 3-kinase, receptor and non-receptor kinases, mitogen activated protein kinases (MAPK), etc. (de Gasparo et al., 2000; Hunyady et al., 2004; Oliveira et al., 2007). However, Ang II also induces $\mathrm{G}$ protein-independent signaling pathways, such as $\beta$-arrestin-mediated activation of MAP-kinases (McDonald et al., 2000; Wei et al., 2003; Szidonya et al., 2007). In 


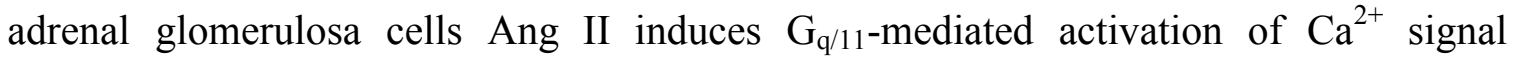
generation and $\mathrm{PKC}$ activation, which is followed by activation of diverse signaling pathways, including stimulation of MAP kinases, tyrosine kinases, lipoxygenase production, phospholipase D and phospholipase $A_{2}$ (Hajnoczky et al., 1992; Gu et al., 2003; Spät and Hunyady, 2004; Shah et al., 2006; Bollag et al., 2007). Ang II can also activate $\mathrm{G}$ protein-independent signaling mechanisms of type 1 angiotensin receptor (AT1R), which can be exclusively activated by Sar $^{1}-\mathrm{Ile}^{4}-\mathrm{Ile}^{8}$-AngII (Wei et al., 2003, Daniels et al., 2005).

In adrenal zona glomerulosa cells Ang II regulates aldosterone secretion by stimulating its synthesis. The initial phase of Ang II-induced stimulation of aldosterone production is mediated by increased availability of the precursor molecules, including cholesterol and NADPH, whereas long term activation of aldosterone synthesis requires increased expression of steroid-transporting and steroidogenic proteins, such as StAR protein and CYP11B2 or aldosterone synthase (Bassett and White et al., 2004; Spät and Hunyady, 2004; Capponi, 2004). Mechanisms of the Ang II-induced expression of CYP11B2 have been investigated in H295R human adrenocarcinoma cells and primary glomerulosa cells (Spät 1988; Clyne et al., 1996; Natarajan et al., 2002; Spät and Hunyady, 2004; Rainey et al., 2004; Bassett and White et al., 2004). It has been suggested that paracrine delivery of steroid precursors to CYP11B2 may also contribute to aldosterone synthesis, which underlines the importance of this enzyme in aldosterone biosynthesis (Vinson, 2004). In H295R cells Ang II-induced activation of human CYP11B2 gene involves $\mathrm{Ca}^{2+}$ signal-mediated activation of calmodulin kinases (CAMK), which regulates the transcription and/or activity of early transcription factors, such as members of the AP-1 complex (including FOS and JUN), the early growth response (EGR) factor family, CREB, Nur-related factor 1 (Nurr1 or NR4A2) and nerve growth factor-induced clone B (NGFIB or NR4A1) (Bassett and White et al., 2004; Bassett and Suzuki et al., 2004; Spät and Hunyady, 2004). Early transcription factors NGFIB (NR4A1) and Nurr1 (NR4A2), which are important regulators of CYP11B2 expression, belong to the class 4 receptors of nuclear receptor (NR) family (Li et al., 2006; Lonard et al., 2007).

Gene targets of Ang II in glomerulosa cells were defined in H295R cells (Romero et al., 2004, Bassett and White et al., 2004). Comparative microarray studies by Nogueira et al. (2007) in human, rat and bovine cells revealed a similar pattern of Ang II-induced genes in these cells. Members of the NR family of transcription factors were among the most induced genes in all three cell types, which is consistent with the role of these proteins in the Ang II-induced regulation of steroidogenesis. Both in H295R cells and in rat glomerulosa cells NR4A2 and NR4A1 were the most induced NR genes (Nogueira et al., 2007). In the present study we aimed to investigate the quantitative contribution of $G$ protein-mediated signaling mechanisms, including PKC and CAMK pathways, and the $\mathrm{G}$ protein-independent mechanisms to the effect of Ang II on the expression of CYP11B2 and transcription factors Nurr1 (NR4A2) and NGFIB (NR4A1) in H295R human adrenocortical cells and in primary rat glomerulosa cells to evaluate the general relevance of these mechanisms in the regulation of aldosterone synthesis.

\section{Materials and Methods}




\subsection{Cell culture}

H295R human adrenocortical cells (generously provided by Dr. William E. Rainey) were cultured in DMEM/-F12 (1:1) medium (with 1-Glutamine, $15 \mathrm{mM}$ HEPES, purchased from Invitrogen) supplemented with $2 \%$ Ultroser FS serum (Biosepra, Villeneuve-la-Garenne, France), 1\% ITS-1 serum (Sigma-Aldrich) and 1\% Pen/Strep antibiotics (Sigma-Aldrich). Cell monolayers were subcultured into culture flasks and transferred onto 6-well plates before used. Cells were incubated in $5 \% \mathrm{CO}_{2}$ at $37^{\circ} \mathrm{C}$. Cells were passaged 3-13 times.

\subsection{Animals}

Male Wistar rats (170-200 g, Charles River Laboratories-Semmelweis University, Budapest) kept on a standard semisynthetic diet were used with the approval (No. 109/003/2007) of the Animal Health and Food Control Office of Budapest. All procedures followed legal and institutional guidelines of animal care.

\subsubsection{Preparation of rat glomerulosa cells}

Rat glomerulosa cells were prepared from the adrenal capsular tissue with collagenase digestion, as described previously (Spät et al., 1989). Isolated cells were plated on polylysine-coated 6-well plates and incubated in $5 \% \mathrm{CO}_{2}$ at $37{ }^{\circ} \mathrm{C}$ in a medium consisting of modified Krebs-Ringer-bicarbonate solution and M199 culture medium (final concentrations: $145 \mathrm{mM} \mathrm{Na}^{+}, 3.6 \mathrm{mM} \mathrm{K}^{+}, 0.5 \mathrm{mM} \mathrm{Mg}^{2+}, 1.2 \mathrm{mM} \mathrm{Ca}^{2+}$ ), (Rohács et al., 1994) overnight. Collagenase type one was purchased from Worthington Biochemicals (Lakewood, NJ). Chemicals were purchased from Sigma-Aldrich.

\subsection{Treatment protocols}

H295R cells were kept serum-starved overnight prior to stimulation. Rat glomerulosa cells were maintained in a serum-free medium. In Protocol 1 dose response curves for Ang II ( $1 \mu \mathrm{M}$, Sigma-Aldrich) from $100 \mathrm{pM}$ to $1 \mu \mathrm{M}$ were obtained in both cell types. Cells were stimulated with Ang II for 1 and 6 hours separately. In Protocol 2 cells were stimulated with Ang II for 1-2-4-6 hours. In Protocol 3 MAPK kinase (MEK) inhibitor (PD98059, $20 \mu \mathrm{M}$, Sigma-Aldrich), PKC inhibitor (bisindolylmaleimide-1, BIM1, $3 \mu \mathrm{M}$ and $10 \mu \mathrm{M}$, Merck Chemicals Ltd., Darmstadt, Germany), calmodulin kinase inhibitor (KN93, $10 \mu \mathrm{M}$, Calbiochem) and epidermal growth factor receptor (EGFR) inhibitor (AG1478, $1 \mu \mathrm{M}$, Calbiochem) were added half hour prior to 1-hour Ang II (100 nM) stimulation. In Protocol 4 cells were treated with PD98059, BIM1, KN93 and AG1478 prior to 6-hour Ang II-stimulation $(1 \mu \mathrm{M})$. In Protocol 5 H295R cells were treated with 1 $\mu \mathrm{M}$ Ang II or $30 \mu \mathrm{M} \mathrm{Sar}{ }^{1}-\mathrm{Ile}^{4}-\mathrm{Ile}^{8}$-AngII (Bachem, Torrance, CA) for 6 hours in order to investigate Ang II-induced G protein-independent effects.

\subsection{Protocol for RNA extraction and real-time PCR}


Cells were washed twice with sterile PBS (with composition in mM: $\mathrm{NaCl} 137, \mathrm{KCl}$ 2.7, $\mathrm{Na}_{2} \mathrm{HPO}_{4} 10.1, \mathrm{KH}_{2} \mathrm{PO}_{4} 1.8, \mathrm{pH} 7.4$ ), and removed with trypsin-EDTA (1:4 dilution into PBS), total RNA was extracted (RNeasy mini kit, Qiagen) and reverse transcription was carried out according to manufacturer's instructions (Fermentas) was made.

Real-time PCR assays were performed on capillary-based LightCycler 1.5 System (Roche Applied Science) with SYBR Green method. Reactions were performed in a LightCycler 1.5 real-time PCR equipment (Roche) using Taq polimerase. Primers were designed (Table 1) and synthesized by Sigma-Genosys (Germany) or purchased from SuperArray Biosciences (Frederick, MD). Cycling conditions were: 10 min preincubation at $95 \mathrm{C}, 45-50$ cycles of $95 \mathrm{C} 10 \mathrm{sec}, 62 \mathrm{C} 5 \mathrm{sec}$ and $72 \mathrm{C} 15 \mathrm{sec}$. Fluorescence data including melting curves were obtained. For normalization glyceraldehyde-3-phosphate dehydrogenase (GAPDH) housekeeping gene was used. Efficiency for each primer pair was determined by using serial dilutions of the PCR product. Fold ratios of gene expressions were calculated as follows:

$$
\text { Ratio }=\mathrm{E}^{\Delta \mathrm{Ct} \text { target gene }} / \mathrm{E}^{\Delta \mathrm{Ct} \mathrm{GAPDH}}
$$

Ct was calculated by the second derivative method using LightCycler 3.5 Software. $\Delta \mathrm{Ct}$ is the difference in $\mathrm{Ct}$ values obtained from control sample and pharmacologically treated sample.

Messenger RNA levels of aldosterone-synthesizing enzyme (CYP11B2) and early transcription factors nuclear receptor subfamily 4, group A, member 1 (NR4A1 or NGFIB) and nuclear receptor subfamily 4, group A, member 2 (NR4A2 or Nurr1) were determined in human and rat adrenocortical cells.

\subsection{Immunostaining and confocal microscopy}

Rat glomerulosa cells were kept in serum-free medium, whereas H295R cells were serum-starved overnight prior to stimulation. In Protocol 6 cells were stimulated with 1 $\mu \mathrm{M}$ Ang II for 24 hours, and the cells were restimulated with $1 \mu \mathrm{M}$ Ang II after 12 hours. Cells were fixed with 4\% paraformaldehide (diluted in PBS) on glass coverslips, permeabilized with $0.1 \%$ Triton, incubated with primary and secondary antibodies. Nurr1 (sc-990) and Nur77 (NGFIB, sc-5569) antibodies were purchased from Santa Cruz Biotechnology, and visualized rhodamine-labeled anti-rabbit antibody (Jackson ImmunoResearch-Izinta Trading Co., Hungary). Rhodamine fluorescence was detected with confocal microscopy and images were analyzed with Zeiss LSM Image Browser (Carl Zeiss $\mathrm{GmbH}$ ) and ImageJ softwares.

\subsection{Statistical analysis}

Data are presented as Means \pm SEM. For paired data Student's $t$-test was applied; for multiple comparisons one-way or two-way ANOVA with repeated measures followed by Tuckey's post hoc test were applied. Fold changes of gene expression levels are plotted against control. $\mathrm{P}<0.05$ was considered significant. 


\section{Results}

3.1. Dose-response curves of Ang II-induced expression of early transcription factors NGFIB (NR4A1) and Nurrl (NR4A2) in H295R and rat adrenal glomerulosa cells (Protocol 1)

1 hour Ang II-stimulation from $100 \mathrm{pM}$ to $1 \mu \mathrm{M}$ caused a dose-dependent increase in the expression of early transcription factor genes, NR4A1 and NR4A2 both in H295R cells and in rat glomerulosa cells (Fig. 1, n=3-6) that reached maximum at $100 \mathrm{nM}$ or 1 $\mu \mathrm{M}$ Ang II concentration after 1 hour or 6 hours stimulation, respectively. The maximum expression level for NR4A1 and NR4A2 was 15.9 \pm 2.0 - and 23.1 \pm 6.2 -fold in H295R

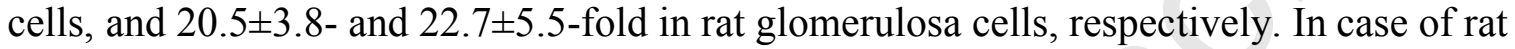
glomerulosa cells NR4A2 was only minimally activated by Ang II at 6 hours (Fig. 1, panel D, and see also Fig. 2, panel E). Increasing the duration of Ang II-stimulation 1 hour to 6 hours induced a right shift of the dose response curves in all conditions. In the following experiments the Ang II concentration was selected to obtain maximal stimulation. Therefore, in protocol 3 with 1 hour of Ang II-stimulation we applied 100 $\mathrm{nM}$ of Ang II. Since after 6-hour stimulation the Ang II-induced gene activation did not reach its maximum level at $100 \mathrm{nM}$ Ang II concentration, thus in protocols 4-6, with at least 6 hours of Ang II-stimulation, we applied $1 \mu \mathrm{M}$ of Ang II to induce maximal stimulation.

3.2. Time-dependence of Ang II-induced expression of early transcription factors NGFIB (NR4A1) and Nurr 1 (NR4A2) as well as aldosterone synthase in H295R and rat adrenal glomerulosa cells (Protocol 2)

In H295R cells Ang II $(1 \mu \mathrm{M})$ caused a rapid increase of the mRNA levels of early transcription factors NR4A1 (NGFIB) and NR4A2 (Nurr1). Maximal increase of the expression levels of these genes were obtained within 1 hour stimulation with Ang II,

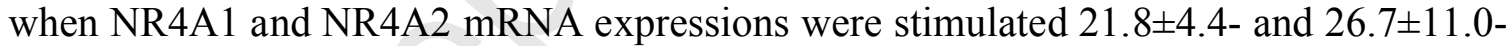
fold over their control levels, respectively $(\mathrm{n}=4)$, which was slowly decreased to 13.5 \pm 4.9 - and 13.3 \pm 4.5 -fold over control levels, respectively, after 6 hours of Ang II stimulation (n=4) (Fig. 2, panels A-B). Expression of CYP11B2 mRNA showed a much slower increase in H295R cells, which increased by 6.8 \pm 2.5 -fold after 6 hours of Ang II stimulation ( $\mathrm{n}=4$ ) (Fig. 2, panel C). In rat adrenal glomerulosa cells, Ang II-induced upregulation of early transcription factors, NR4A1 and NR4A2, was rapid and more transient compared to H295R cells. The maximum levels of NR4A1 and NR4A2 expressions were obtained after 1 hour stimulation with Ang II, at the levels of 31.7 \pm 4.8 and 33.8 \pm 6.8 -fold over the control levels $(\mathrm{n}=3)$, respectively. After prolonged stimulation with Ang II the mRNA expression levels of these transcription factors rapidly decreased to 5.9 \pm 1.1 - and 2.9 \pm 0.4 -fold, respectively, after 6 hour stimulation (n=3) (Fig. 2, panel DE). In rat cells CYP11B2 reached the maximum expression level around 2 hours of stimulation (7.4 \pm 1.8 -fold, $\mathrm{n}=3)$ (Fig. 2, panel F).

3.3. Effects of Ang II on the localization of NGFIB and Nurrl in human and rat glomerulosa cells (Protocol 6) 
Cellular localization of early transcription factors, Nurr1 and NGFIB, in adrenocortical cells at the protein level was studied using confocal microscopy. Confocal imaging of Nurr1 shows its extensive localization in the cell nucleus of both H295R and rat glomerulosa cells (Fig. 3, panel A). Prolonged stimulation with Ang II increased Nurrl fluorescence intensity of H295R cells, but not of rat glomerulosa cells (Fig. 3, panel A), which is consistent with the transient kinetics of mRNA expression in rat cells. Ang II-induced nuclear translocation of Nurr1 protein, which was more pronounced in H295R cells (Fig. 3, panel A, B). Cell nucleus/cytoplasm fluorescence density ratios were increased from $3.01 \pm 0.4$ to $5.34 \pm 0.5$ in $\mathrm{H} 295 \mathrm{R}$ cells and from $2.38 \pm 0.16$ to $3.77 \pm 0.4$ in rat glomerulosa cells, respectively (Fig. 3, panel B).

Early transcription factor NGFIB localizes both to the cytoplasm and the nucleus of H295R and rat glomerulosa cells, as well (Fig. 4, panel A). Prolonged stimulation with Ang II did not change significantly the total fluorescence intensity of NGFIB in these cells, however, Ang II induced nuclear translocation of NGFIB in both types of cells. Cell nucleus/plasma fluorescence density ratios were increased from $1.96 \pm 0.02$ to $3.8 \pm 0.4$ in $\mathrm{H} 295 \mathrm{R}$ cells and from $1.32 \pm 0.04$ to $2.17 \pm 0.27$ in rat glomerulosa cells, respectively (Fig. 4, panel B).

\subsection{Effects of inhibitors on Ang II-induced expression of aldosterone synthase, early transcription factors NGFIB (NR4A1) and Nurrl (NR4A2) in human and rat adrenocortical cells (Protocols 3 and 4)}

In H295R cells 1 hour Ang II-stimulation (100 nM) enhanced expression of NR4A1 and NR4A2 genes by 14.5 \pm 2.6 - and 27.6 \pm 6.4 -fold $(n=4)$, respectively (Fig. 5, panels A and B). In rat glomerulosa cells 1 hour Ang II-stimulation induced NR4A1 and NR4A2 genes by 30.4 \pm 7.2- and 22.1 \pm 3.5 -fold ( $\mathrm{n}=3-5$ ) (Fig. 5, panels $\mathrm{C}$ and $\mathrm{D}$ ), respectively. Since in H295R and rat glomerulosa cells after 1 hour Ang II stimulation the induction of CYP11B2 was minimal (Fig. 2, panels $\mathrm{C}$ and F), the mechanism of this response was not investigated at this early phase of Ang II stimulation. After pretreatment of the cells with MEK, PKC and CAMK inhibitors statistically significant reduction of the Ang II-induced NR4A1 response was not observed in H295R cells (Fig. 5, panel A), and only the CAMK inhibitor caused statistically significant partial inhibition of this response in rat glomerulosa cells (Fig. 5, panel C). The Ang II-induced early induction of NR4A2 was very effectively reduced by CAMK inhibition both in H295R cells (to 4.0 1 1.4-fold) and in rat glomerulosa cells (to 2.9 \pm 0.8 -fold). Although $\mathrm{MEK}$ and $\mathrm{PKC}$ inhibitors did not affect the NR4A1 and NR4A2 responses in rat glomerulosa cells - however BIM1 moderately decreased Ang II-induced NR4A2 expression that did not reach statistical significance - (Fig. 5, panels C-D), these inhibitors moderately interfered with the Ang II-induced NR4A2 response in H295R cells (Fig. 5, panel B, $\mathrm{p}<0.05$, $\mathrm{n}=4$ ).

Additional studies were performed to investigate the late phase of the Ang II response. In H295R cells prolonged (6-hour) administration of Ang II ( $1 \mu \mathrm{M})$ enhanced the expression of NR4A1, NR4A2 and CYP11B2 by 12.6 $\pm 0.5-, 15.7 \pm 1.9-$ and $4.6 \pm 1.0$ fold $(n=4-8)$, respectively (Fig. 6, panels A-C). Under these experimental conditions in the MEK inhibitor PD98059 pretreated cells increased mRNA expression levels of NR4A1, NR4A2 and CYP11B2 were detected in non-stimulated cells by $1.7 \pm 0.06-$, 
2.34 \pm 0.3 - and 1.6 \pm 0.2 -fold $(n=4-8)$, respectively (Fig. 6, panels A-C, $p<0.05$ ). The MEK inhibitor, which significantly increased the basal activities of NR4A1, NR4A2 and CYP11B2 also statistically significantly interfered with the Ang II-induced responses of the expressions of these genes (Fig. 6, p $<0.05$ ). Basal expression of genes in response to PKC inhibition with BIM1 did not change in H295R cells (Fig. 6), and even an increased dose of BIM1 $(10 \mu \mathrm{M})$ did not change the expression of CYP11B2 (data not shown). Although BIM1 decreased Ang II-induced expression of NR4A1 and NR4A2 significantly ( $p<0.05$ by one-way ANOVA without interaction), the moderate decrease in CYP11B2 expression was not significant. CAMK inhibition had no effect on the Ang IIinduced NR4A1 expression (Fig. 6, panel A), but significantly interfered with the Ang IIinduced stimulation of NR4A2 (Fig. 6, panel B), similarly to the results obtained in Fig. 5B. The Ang II-induced CYP11B2 response was completely abolished by CAMK inhibitor treatment. The effect of CAMK inhibitor in non-stimulated cells was also significant (Fig. 6, panel C, p <0.05). In parallel experiments, AG1478, an EGFR kinase inhibitor, did not have significant effects on Ang II-induced gene activations (data not shown).

In contrast to the observations in $\mathrm{H} 295 \mathrm{R}$ cells, in rat glomerulosa cells the inhibitors alone did not cause any elevation of the gene expression levels (Fig. 7, n=4-5). PKC inhibitor BIM1 slightly increased CYP11B2 expression that did not reach statistical significance (Fig. 7, panel B). Increasing the dose of BIM1 to $10 \mu \mathrm{M}$ even did not change the expression of CYP11B2 (data not shown). 6-hour Ang II-stimulation induced expression of NR4A1 and CYP11B2 genes by $7.5 \pm 1.8$ - and 3.7 1.2 -fold, respectively (Fig. 7). Since Ang II-induced activation of NR4A2 mRNA expression was transient and only minimal effect was detected after 6 hours of stimulation with Ang II in rat glomerulosa cells (Fig. 2, panel E), NR4A2 expression studies were excluded from this series of experiments. Ang II-induced late activation of NR4A1 was slightly reduced by MEK, PKC and CAMK inhibitors, but these effects were not statistically significant (Fig. 7, panel A). Ang II-induced CYP11B2 expression was completely inhibited by the CAMK inhibitor $(\mathrm{p}<0.05)$, whereas the other inhibitors had no effect on this response (Fig. 7, panel B). AG1478 did not have significant effects on Ang II-induced gene activations (data not shown).

\subsection{G protein-independent signaling effects of Ang II in H295R cells (Protocol 4)}

SII-Ang II was applied in order to investigate $\mathrm{G}$ protein-independent signaling effects of Ang II (Wei et al., 2003, Fig. 8). In H295R cells Ang II-induced expression of NR4A1, NR4A2 and CYP11B2 genes at 6-hours of stimulation (see also at Fig. 6) was compared with the effects of SII-Ang II. SII-Ang II induced the expression of NR4A1, NR4A2 genes by $2.1 \pm 0.5-, 2.0 \pm 0.8$ - and $2.9 \pm 0.9$-fold $(\mathrm{n}=4)$, respectively, which was significant in case of NR4A1 and CYP11B2 (Fig. 8, panel A). In case of rat glomerulosa cells 6 hours of stimulation with Ang II induced significant increase in mRNA levels of NR4A1, NR4A2 and CYP11B2 genes to 10.8 $\pm 2.8-, 2.6 \pm 0.3$ - and $8.5 \pm 1.2$-fold ( $\mathrm{n}=3$ ), respectively. However, SII-Ang II did not cause significant changes in gene expression levels in these cells (Fig. 8, panel B).

\section{Discussion}


Ang II is a major physiological regulator of the aldosterone secretion of adrenal glomerulosa cells. The mechanism of the regulation of aldosterone synthesis involves stimulation of the cholesterol supply to the mitochondria, increased reduction of pyridine nucleotides in the mitochondria providing NADPH for the steroid biosynthesis and induction of the proteins required for aldosterone production (Spät et al., 1981; Spät 1988; Spät et al., 1991; Bassett and White et al., 2004; Spät and Hunyady, 2004; Rossier and Capponi, 2004). Earlier studies have demonstrated that in the adrenal cortex transcription factors, such as NGFIB, Nurr1, SF-1, ATF-1, CREB, GATA4, GATA6 can induce promoter activation of steroidogenic genes, including CYP11B2, CYP17, CYP21, CYP11A, HSD3B2 (Davis et al., 1994; Bassett and White et al., 2004; Kelly et al., 2004; Bassett et al., 2005). In zona glomerulosa cells Ang II stimulates rapidly the expression and synthesis of the StAR protein leading to increased cholesterol supply of the mitochondria, whereas induction of CYP11B2 occurs more slowly during the late phase of the Ang II-induced aldosterone response (Enyeart et al., 1996; Capponi, 2004; Rainey et al., 2004; Bassett and Suzuki et al., 2004).

The agonist-induced activation of CYP11B2 gene expression is preceded by early induction of transcription factors and other genes, which has been characterized in detail in H295R cells (Clyne et al., 1996; Clyne et al., 1997; Rainey et al., 2004). The CYP11B2 gene contains a cAMP-response element (CRE) and at least three additional cis-acting regulatory elements (NBRE-1, Ad-4 and Ad-5) in its promoter region, which serve as targets for transcription factors, including Nurr1, NGFIB, SF-1, ATF-1, COUP etc. (Bassett and White et al., 2004; Capponi, 2004). It has been suggested that members of the NGFIB family of orphan nuclear receptors, Nurr1 and NGFIB, have major roles in the Ang II-induced stimulation of CYP11B2 expression in adrenocortical cells (Bassett and Suzuki et al., 2004; Lu et al., 2004; Rainey et al., 2004). Microarray analysis of the Ang II-induced gene expression patterns has been studied in H295R human adrenocortical cells, in human adrenal glands, and primary rat and bovine glomerulosa cells (Romero et al., 2004; Rainey et al., 2004; Bassett at al., 2005; Romero et al., 2007; Nogueira et al., 2007). In a recent study early gene expression after Ang II stimulation has been compared in these adrenocortical model systems (Nogueira et al., 2007). The microarray comparison revealed $20-36 \%$ similarity in the Ang II-induced genes in bovine, human and rat cells. However, several genes were increased in all three models, including activating transcription factor 3 (ATF3), B-cell translocation gene (BTG2), cFOS, FOSB, JUNB, NR4A1, NR4A2, NR4A3 and EGR-1. Interestingly, although members of the NGFIB family of orphan nuclear receptors were among the top genes induced by Ang II in all three cells, in the three species the quantitatively largest response occurred in different members of this family: Ang II-induced largest response was observed in NR4A1 (NGFIB), NR4A2 (Nurr1) and NR4A3 in rat glomerulosa cells, bovine glomerulosa cells and H295R cells, respectively (Nogueira et al., 2007). The Ang II-induced genes in these adrenocortical cells, and their roles in zona glomerulosa function has been reviewed in a paper of this issue (Nogueira et al., in press, in this issue).

In the present study we compared the mechanism of Ang II-induced CYP11B2 expression in H295R cells and primary rat adrenal glomerulosa cells. The dose- and timedependent kinetics of Ang II-induced gene expression was different between human and 
rat adrenocortical cells. Ang II-induced dose-responses in NR4A1 and NR4A2 expressions were maximal at $100 \mathrm{nM}$ concentration of Ang II when cells were stimulated for 1 hour, however, the curves were shifted to the right showing a lower potency of Ang II when the cells were stimulated for 6 hours (Fig. 1). The apparently lower potency of Ang II in experiments when stimulation was 6 hours or longer may be caused by degradation of the peptide ligand during prolonged stimulation. Time-dependent kinetics of Ang II-stimulation indicated differences in gene activations among the two cell types. Although both in human and rat adrenocortical cells transcription factors NR4A1 and NR4A2 show an activation peak by 1 hour of stimulation followed by a decline in the response, in H295R cells the kinetics of decline is slower compared to rat glomerulosa cells (Fig. 2). The Ang II-induced NR4A2 response was particularly rapid in rat glomerulosa cells, and mRNA level returned close to the control level after 6 hours of stimulation. Ang II-induced activation of CYP11B2 gene peaked at 2-4 hours in rat cells, however in human cells there was a slower increase up to 6 hours. Similar kinetics of Ang II-induced gene expression in H295R cells was observed by Romero et al., although in that study the earliest time point the authors investigated was 3 hours (Romero et al., 2004).

Immunofluorescence imaging of early transcription factors Nurrl and NGFIB revealed different localization patterns of these transcription factors in adrenocortical cells. In resting cells Nurr1 can be found predominantly in the cell nucleus of both human and rat adrenocortical cells; however NGFIB shows a more dense appearance also in the cytoplasm. Long term stimulation with Ang II lead to a reproducible increase of Nurr1 protein density in H295R cells, but not in rat glomerulosa cells, which is consistent with the transient nature of the Nurr1 mRNA response in the rat cells. In non-stimulated human prostate cancer cells NGFIB (TR3) was also found to exhibit nuclear localization (Li et al., 2000). However Ang II also induced nuclear translocation of NGFIB and Nurr1 both in human and rat adrenocortical cells, which is consistent with the role of these transcription factors in the induction of steroidogenic enzymes. It has been reported that NGF-induced phosphorylation of NGFI-B in PC12 phaeochromocytoma cells results in a transient translocation of the NGFI-B-RXR heterodimer complex out of the nucleus using nuclear export signals within NGFI-B (Katagiri et al., 2000). On the other hand, it is also well-established that calcium-mediated activation of calcium/calmodulin-dependent protein kinase I (CAMKI) and possibly CAMKIV regulates human CYP11B2 expression (Condon et al., 2002; Bassett and Suzuki et al., 2004, Bassett and White et al, 2004). Based on these findings it is tempting to speculate that CAMK-mediated phosphorylation of NGFIB and/or Nurr1 is responsible for the increase accumulation of these factors in the cell nucleus. It has also been suggested that NGFIB may also translocate to the cytoplasm upon activation of apoptosis stimuli (Katagiri et al., 2000; Li et al., 2000). These findings are consistent with the proposal that agonist-induced nuclear translocation of these factors contributes to the Ang II-induced regulation of aldosterone biosynthesis.

In agreement with earlier findings suggesting that CAMKs play a predominant role in the regulation of aldosterone production stimulated by Ang II, $\mathrm{K}^{+}$and cAMP in rat and bovine glomerulosa cells (Pezzi et al., 1997; Condon et al., 2002; Gambaryan et al., 2006), we also found, that inhibition of the activity of CAMKs eliminates the Ang IIinduced induction of CYP11B2, and inhibits the stimulation of Nurr1, and to a lesser extent NGFIB in rat glomerulosa cells and in H295R cells. However, the reduced 
sensitivity of the NGFIB response to Ang II, compared to that of CYP11B2, suggests, that induction of NGFIB is not sufficient to achieve the CYP11B2 response and/or CAMK-mediate regulation is not limited to an effect on NGFIB, and other targets may play a role in this process.

The role of ERK activation in the mechanism of Ang II-induced aldosterone secretion and CYP11B2 expression response of adrenal glomerulosa cells is controversial. Natarajan et al. (2002) found that Ang II-induced activation of p38 MAP kinases, but not ERK, plays a role in the Ang II-induced aldosterone response in H295R adrenocortical cells. Both p42/44 and p38 MAPKs have been shown to be involved in the Ang IIinduced aldosterone production in glomerulosa cells with the involvement of the RhoRac pathways (Otis and Gallo-Payet, 2007). However, the inhibitory effect of MEK1 inhibition on the Ang II-induced aldosterone response of bovine adrenal glomerulosa cells and H295R cells has also been reported (Osman et al., 2002; Suzuki et al., 2004). On the other hand, LeHoux and Lefebvre (2004) found, that MEK inhibitor PD98059 activated CYP11B2 promoter activity suggesting, that p44/42 MAPK kinase pathway is inhibitory for basal CYP11B2 promoter activity. Our data demonstrate that MEK1 inhibition, in agreement with the findings of LeHoux and Lefebvre, stimulates the basal expression level of CYP11B2 in H295R cells; but not in rat adrenal glomerulosa cells. However, our data also suggest that MEK1 inhibition with PD98059 also interferes with the Ang II-induced CYP11B2 induction in H295R cells, but this effect is also absent in rat glomerulosa cells. This finding is consistent with the data of Osman et al. (2002) and Suzuki et al. (2004) on the inhibitory effect of MEK1 inhibition on the Ang II-induced aldosterone response. Both inhibitors U0126 and PD98059 were shown to decrease Ang II-induced aldosterone production in adrenal glomerulosa cells (Osman et al., 2002) and U0126 was also effective in H295R cells (Suzuki et al., 2004). However, the opposite effect of MEK1 inhibition with PD98059 on CYP11B2 expression in control and Ang IIstimulated adrenocortical cells suggests that ERK activation can lead to different consequences in control and Ang II-stimulated cells. Although the explanation for this discrepancy is not clear, it is important to mention that phospho-ERK activity can be present in different cellular compartments, such as in the cytosol and the nucleus, but accumulation of phospho-ERK on the surface of endosomal membranes has also been reported in Ang II-stimulated cells (Luttrell et al., 2001). Inhibition of the ERK activity in different compartments may explain the different effects of MEK1 inhibition in control and Ang II-stimulated H295R cells.

Our data suggest that MEK1 inhibition also interferes with the Ang II-induced stimulation of NR4A1 and NR4A2 expression in H295R cells. The role of MAP kinases in the activation and induction of NR4As in different cells types has also been reported (Katagiri et al., 2000; Darragh et al., 2005; Li et al., 2006). The effect of MEK1 inhibition on NR4A1 and NR4A2 expression may contribute to the observed inhibition of Ang II-induced CYP11B2 response in H295R cells.

Earlier studies have suggested that PKC can inhibit the steroidogenesis of adrenal glomerulosa cells. In rat adrenal glomerulosa cells PKC activation and inhibition lead to inhibition and stimulation of the Ang II-stimulated aldosterone response, respectively (Hajnoczky et al., 1992). In accordance with the earlier observations, treatment of H295R cells with BIM1 increased CYP11B2's promoter activity (LeHoux and Lefebvre, 1998) also showing a negative regulatory effect of PKC on the transcription of CYP11B2. More 
PKC inhibitors were found to stimulate aldosterone output, such as GF109203X and staurosporine as well (Lehoux et al., 2001, Hajnoczky et al., 1992, Spät and Hunyady, 2004). Lehoux et al. (2001) suggests, that the seemingly paradoxical effect of Ang II on stimulating aldosterone biosynthesis while activating DAG-dependent PKC that inhibits CYP11B2 expression may be explained by that Ang II exerts a positive action on CYP11B2 expression by other signaling pathway(s) yet to be discovered, and a negative action through the PKC signaling pathway. The negative regulatory action would be delayed in comparison to the positive action producing a feedback control to restore normal levels of CYP11B2 expression and to end the enhancing Ang II-action (LeHoux et al., 2001). Based on the literature a rather negative regulatory action of PKC on acute control of aldosterone synthesis has been suggested (Spät and Hunyady, 2004). Several isoforms of PKC have been found in adrenocortical cells that make it more difficult and complex to understand the role of PKC in the signaling. Lehoux et al. (2001) found in agreement with previous reports, that the rat adrenal zona glomerulosa expressed PKC $\alpha$ and $-\varepsilon$ and $\mathrm{PKC}$ isoforms $\alpha,-\varepsilon$, and $-\zeta$ were also commonly expressed in the human adrenocortical NCI-H295 cell line. They also found, that DAG-dependent PKC isoforms can suppress whereas the atypical PKC $\zeta$ can enhance the basal expression of CYP11B2 in transfected NCI-H295 cells. Lehoux and Lefebvre found, that overexpression of constitutive active PKCa and PKCe inhibited Ang II-induced CYP11B2 gene transcription, and suggested that PKC $\varepsilon$ inhibited Ang II-stimulated CYP11B2 gene expression via MEK-ERK signaling pathway in H295R cells (LeHoux and Lefebvre, 2006; Lehoux and Lefebvre, 2007).

Although, we have found that inhibition of PKC with BIM1 had no major effect on the basal and Ang II-stimulated CYP11B2 expression (there was a slight increase in basal CYP11B2 in rat glomerulosa cells, which did not reach statistical significance, Fig. 7, panel B), suggesting that $\mathrm{PKC}$ has no major role in the CYP11B2 response after prolonged Ang II stimulation (Fig. 6, panel C and Fig. 7, panel B). We also have found, that 1-hour inhibition of PKC with BIM1 did not alter basal CYP11B2 expression in rat glomerulosa cells as well, (data not shown), however, these cells showed some Ang IIinduced CYP11B2 expression at this time point in contrast with H295R cells (Fig. 2, panel $\mathrm{C}$ and 2, panel $\mathrm{F}$ ). Regarding the role of PKC in the expression of NR4A1 and NR4A2 genes we have found, that BIM1 did not modify the basal expression level of early transcription factors, however, the Ang II-induced expression of NR4A1 and NR4A2 was reduced by BIM1 treatment in H295R cells.

Ang II-induced PKC activation can lead to ERK activation in several cell types (Hunyady and Catt, 2006; Shah et al., 2004). Another mechanism of Ang II-induced ERK activation is EGFR transactivation, which can be detected in adrenal glomerulosa cells as well (Shah et al., 2004; Shah et al., 2006). However, we did not find a consequent role of $\mathrm{AT}_{1}$ receptor-EGFR- transactivation in the Ang II-induced expressions of CYP11B2, NR4A1 and NR4A2 in human and rat adrenocortical cells.

In addition to $\mathrm{G}$ protein-dependent mechanisms, Ang II can also stimulate G proteinindependent signal transduction mechanisms by directly associating with signaling molecules, such as $\beta$-arrestins and tyrosine kinases (Hunyady and Catt, 2006, Wei et al., 2003). It has been suggested, that $\beta$-arrestin binding, which terminates receptor-G protein coupling, also initiates a second wave of signal transduction in which the "desensitized" receptor functions as a critical structural component of a mitogenic signaling complex 
(Luttrell et al., 1999). As in other G protein-coupled receptors, activation of the $\mathrm{AT}_{1} \mathrm{R}$ leads to its phosphorylation by specific receptor kinases and binding of $\beta$-arrestin, which uncouples it from $G$ proteins and also serves as an adaptor for clathrin-mediated internalization. $B$-arrestins also serve as scaffolds to organize the formation of signaling complexes that mediate $\mathrm{AT}_{1} \mathrm{R}$-mediated activation of ERK and JNK3 MAPKs (Hunyady and Catt, 2006). Previous studies on a mutant $\mathrm{AT}_{1} \mathrm{R}$ that cannot couple to $\mathrm{G}$ proteins have shown that $\beta$-arrestin2-mediated ERK activation can occur in the absence of $\mathrm{G}$ proteinactivation (Hunyady and Catt, 2006). G protein-independent mechanisms through $\mathrm{AT}_{1} \mathrm{R}$ can be also studied by SII-Ang II, an $\mathrm{AT}_{1}$ receptor ligand that cannot activate $\mathrm{G}$ proteinmediated signaling (Wei et al., 2003; Daniels et al., 2005). We have found, that SII-Ang II-induced partial (about 2-3-fold) induction of NR4A1, NR4A2 and CYP11B2 genes in H295R cells (Fig. 8, panel A) suggesting that Ang II-induced activation of CYP11B2 and early transcription factors Nurrl and NGFIB may be also partially mediated by G protein-independent mechanisms in H295R cells. In rat glomerulosa cells Ang II-induced $\mathrm{G}$ protein-independent signaling does not seem to play a role in the expression of these genes (Fig. 8, panel B). These data suggest that G-independent mechanisms may contribute to the signaling response in human cell lines (e. g. HEK cells), whereas these mechanisms are not detectable in rat adrenal glomerulosa cells.

In conclusion we found, that there are kinetic differences, as well as differences in the mechanisms of Ang II-induced gene activation patterns between H295R cells and rat adrenocortical cells. Although the previously reported calmodulin kinase-mediated stimulation of early transcription factors NGFIB and Nurrl has a key role in Ang IIinduced CYP11B2 activation in both H295R cells and rat adrenal glomerulosa cells, this response has a much more complex mechanism in H295R cells. In addition to CAMKmediated mechanisms, ERK activation and G protein-independent mechanisms also contribute to the mechanism of Ang II-induced CYP11B2 activation in H295R cells.

\section{Acknowledgements}

Supported by Grants OTKA T49851 of Hungarian National Academy of Sciences and Jedlik Ányos 1/010/2005. The authors express their thanks for László Szidonya, Judit Bakacsi, Kata Szabolcsi, András Berekméri, Klára Tóth, Klára Somogyi, Jolán Józan for their expert assistance. 


\section{References}

Bassett, M.H., White, P.C., Rainey, W.E. 2004. The regulation of aldosterone synthase expression. Mol. Cell Endocrinol. 217(1-2):67-74.

Bassett, M.H., Suzuki, T., Sasano, H., White, P.C., Rainey, W.E. 2004. The orphan nuclear receptors NURR1 and NGFIB regulate adrenal aldosterone production. Mol. Endocrinol. 18 (2), 279-290.

Bassett, M.H., Mayhew, B., Rehman, K., White, P.C., Mantero, F., Arnaldi, G., Stewart, P.M., Bujalska, I., Rainey, W.E. 2005. Expression profiles for steroidogenic enzymes in adrenocortical disease. J. Clin. Endocrinol. Metab. 90 (9), 5446-5455.

Bollag, W.B., Kent, P., White, S., Malinova, M., Isales, C.M., Calle, R.A. 2007. Characterization and phospholipase D mediation of the angiotensin II priming response in adrenal glomerulosa cells. Endocrinology. 148 (2), 585-593.

Capponi, A.M. 2004. The control by angiotensin II of cholesterol supply for aldosterone biosynthesis. Mol. Cell. Endocrinol. 217 (1-2), 113-8.

Clyne, C.D., White, P.C., Rainey, W.E. 1996. Calcium regulates human CYP11B2 transcription. Endocr. Res. 22(4):485-492.

Clyne, C.D., Zhang, Y., Slutsker, L., Mathis, J.M., White, P.C., Rainey, W.E. 1997. Angiotensin II and potassium regulate human CYP11B2 transcription through common cis-elements. Mol. Endocrinol. 11 (5), 638-649.

Condon, J.C., Pezzi, V., Drummond, B.M., Yin, S., Rainey, W.E. 2002. Calmodulindependent kinase I regulates adrenal cell expression of aldosterone synthase. Endocrinology. 143 (9), 3651-3657.

Daniels, D., Yee, D.K., Faulconbridge, L.F., Fluharty, S.J. 2005. Divergent behavioral roles of angiotensin receptor intracellular signaling cascades. Endocrinology. 146 (12), 5552-5560.

Darragh, J., Soloaga, A., Beardmore, V.A., Wingate, A.D., Wiggin, G.R., Peggie, M., Arthur, J.S. 2005. MSKs are required for the transcription of the nuclear orphan receptors Nur77, Nurr1 and Nor1 downstream of MAPK signalling. Biochem. J. 390 (Pt 3), 749759.

Davis, I.J., Lau, L.F. 1994. Endocrine and neurogenic regulation of the orphan nuclear receptors Nur77 and Nurr-1 in the adrenal glands. Mol. Cell Biol. 14 (5), 3469-3483. 
Enyeart, J.J., Boyd, R.T., Enyeart, J.A. 1996. ACTH and AII differentially stimulate steroid hormone orphan receptor mRNAs in adrenal cortical cells. Mol. Cell Endocrinol. $124(1-2,97-110$.

Gambaryan, S., Butt, E., Tas, P., Smolenski, A., Allolio, B., Walter, U. 2006. Regulation of aldosterone production from zona glomerulosa cells by ANG II and cAMP: evidence for PKA-independent activation of CaMK by cAMP. Am. J. Physiol. Endocrinol. Metab. 290 (3), E423-33.

de Gasparo, M., Catt, K.J., Inagami, T., Wright, J.W., Unger, T. 2000. International union of pharmacology. XXIII. The angiotensin II receptors. Pharmacol. Rev. 52 (3), 415-472.

Gu, J., Wen, Y., Mison, A., Nadler, J.L. 2003. 12-lipoxygenase pathway increases aldosterone production, 3',5'-cyclic adenosine monophosphate response element-binding protein phosphorylation, and p38 mitogen-activated protein kinase activation in H295R human adrenocortical cells. Endocrinology. 144 (2), 534-543.

Hajnóczky, G., Várnai, P., Buday, L., Faragó, A., Spät, A. 1992. The role of protein kinase-C in control of aldosterone production by rat adrenal glomerulosa cells: activation of protein kinase-C by stimulation with potassium. Endocrinology. 130 (4), 2230-2236.

Hunyady, L., Gáborik, Z., Shah, B.H., Jagadeesh, G., Clark, A.J., Catt, K.J. 2004. Structural determinants of agonist-induced signaling and regulation of the angiotensin AT1 receptor. Mol. Cell Endocrinol. 217 (1-2), 89-100.

Hunyady, L., Catt, K.J. 2006. Pleiotropic AT1 receptor signaling pathways mediating physiological and pathogenic actions of angiotensin II. Mol. Endocrinol. 20 (5), 953-970.

Katagiri, Y., Takeda, K., Yu, Z.X., Ferrans, V.J., Ozato, K., Guroff, G. 2000. Modulation of retinoid signalling through NGF-induced nuclear export of NGFI-B. Nat. Cell Biol. 2 (7), 435-440.

Kelly, S.N., McKenna, T.J., Young, L.S. 2004. Modulation of steroidogenic enzymes by orphan nuclear transcriptional regulation may control diverse production of cortisol and androgens in the human adrenal. J. Endocrinol. 181 (2), 355-365.

LeHoux, J.G., Lefebvre, A. 1998. Transcriptional activity of the hamster CYP11B2 promoter in NCI-H295 cells stimulated by angiotensin II, potassium, forskolin and bisindolylmaleimide. J. Mol. Endocrinol. 20 (2),183-191.

LeHoux, J.G., Dupuis, G., Lefebvre, A. 2001. Control of CYP11B2 gene expression through differential regulation of its promoter by atypical and conventional protein kinase C isoforms. J. Biol. Chem. 276 (11), 8021-8028.

LeHoux, J.G., Lefebvre, A. 2004. On the control of the hCYP11B2 gene expressing cytochrome P450 aldosterone synthase. Endocr. Res. 30 (4), 807-812. 
LeHoux, J.G., Lefebvre, A. 2006. Novel protein kinase C-epsilon inhibits human CYP11B2 gene expression through ERK1/2 signalling pathway and JunB. J. Mol. Endocrinol. 36 (1), 51-64.

LeHoux, J.G., Lefebvre, A. 2007. Angiotensin II activates p44/42 MAP kinase partly through PKCepsilon in H295R cells. Mol. Cell Endocrinol. 265-266, 121-125.

Li, H., Kolluri, S.K., Gu, J., Dawson, M.I., Cao, X., Hobbs, P.D., Lin, B., Chen, G., Lu, J., Lin, F., Xie, Z., Fontana, J.A., Reed, J.C., Zhang, X. 2000. Cytochrome c release and apoptosis induced by mitochondrial targeting of nuclear orphan receptor TR3. Science. 289 (5482), 1159-1164.

Li, Q.X., Ke, N., Sundaram, R., Wong-Staal, F. 2006. NR4A1, 2, 3--an orphan nuclear hormone receptor family involved in cell apoptosis and carcinogenesis. Histol. Histopathol. 21 (5), 533-540.

Lonard, D.M., Lanz, R.B., O'Malley, B.W. 2007. Nuclear receptor coregulators and human disease. Endocr. Rev. 28 (5), 575-587.

Lu L, Suzuki T, Yoshikawa Y, Murakami O, Miki Y, Moriya T, Bassett MH, Rainey WE, Hayashi Y, Sasano H. 2004. Nur-related factor 1 and nerve growth factor-induced clone B in human adrenal cortex and its disorders. J. Clin. Endocrinol. Metab. 89 (8), 4113-4118.

Luttrell, L.M., Ferguson, S.S., Daaka, Y., Miller, W.E., Maudsley, S., Della Rocca, G.J., Lin, F., Kawakatsu, H., Owada, K., Luttrell, DK., Caron, M.G., Lefkowitz, R.J. 1999. Beta-arrestin-dependent formation of beta2 adrenergic receptor-Src protein kinase complexes. Science. 283 (5402), 655-661.

Luttrell, L.M., Roudabush, F.L., Choy, E.W., Miller, W.E., Field, M.E., Pierce, K.L., Lefkowitz, R,J. 2001. Activation and targeting of extracellular signal-regulated kinases by beta-arrestin scaffolds. Proc. Natl. Acad. Sci. U S A. 98 (5), 2449-2454.

McDonald, P.H., Chow, C.W., Miller, W.E., Laporte, S.A., Field, M.E., Lin, F.T., Davis, R.J., Lefkowitz, R.J. 2000. Beta-arrestin 2: a receptor-regulated MAPK scaffold for the activation of JNK3. Science. 290 (5496), 1574-1577.

Natarajan, R., Yang, D.C., Lanting, L., Nadler, J.L. 2002. Key role of P38 mitogenactivated protein kinase and the lipoxygenase pathway in angiotensin II actions in H295R adrenocortical cells. Endocrine. 18 (3), 295-301.

Nogueira, E.F., Vargas, C.A., Otis, M., Gallo-Payet, N., Bollag, W.B., Rainey, W.E. 2007. Angiotensin-II acute regulation of rapid response genes in human, bovine, and rat adrenocortical cells. J. Mol. Endocrinol. 39 (6), 365-374. 
Nogueira, E.F., Bollag, W.B., Rainey, W.E. Angiotensin II regulation of adrenocortical gene transcription. Mol. Cell. Endocrinol. in press, doi:10.1016/j.mce.2008.08.024

Oliveira, L., Costa-Neto, C.M., Nakaie, C.R., Schreier, S., Shimuta, S.I., Paiva, A.C. 2007. The angiotensin II AT1 receptor structure-activity correlations in the light of rhodopsin structure. Physiol. Rev. 87 (2), 565-592.

Osman, H., Murigande, C., Nadakal, A., Capponi, A.M. 2002. Repression of DAX-1 and induction of SF-1 expression. Two mechanisms contributing to the activation of aldosterone biosynthesis in adrenal glomerulosa cells. J. Biol. Chem. 277 (43), 4125941267.

Otis, M., Gallo-Payet, N. 2007. Role of MAPKs in angiotensin II-induced steroidogenesis in rat glomerulosa cells. Mol. Cell. Endocrinol. 265-266:126-30.

Pezzi, V., Clyne, C.D., Ando, S., Mathis, J.M., Rainey, W.E. 1997. Ca(2+)-regulated expression of aldosterone synthase is mediated by calmodulin and calmodulin-dependent protein kinases. Endocrinology. 138 (2), 835-838.

Rainey, W.E., Saner, K., Schimmer, B.P. 2004. Adrenocortical cell lines. Mol. Cell Endocrinol. 228 (1-2), 23-38.

Rohács, T., Bagó, A., Deák, F., Hunyady, L., Spät, A. 1994. Capacitative Ca2+ influx in adrenal glomerulosa cells: possible role in angiotensin II response. Am. J. Physiol. 267 (5 Pt 1), C1246-C1252.

Romero, D.G., Plonczynski, M., Vergara, G.R., Gomez-Sanchez, E.P., Gomez-Sanchez, C.E. 2004. Angiotensin II early regulated genes in H295R human adrenocortical cells. Physiol. Genomics. 19 (1),106-116.

Romero, D.G., Plonczynski, M.W., Welsh, B.L., Gomez-Sanchez, C.E., Zhou, M.Y., Gomez-Sanchez, E.P. 2007. Gene expression profile in rat adrenal zona glomerulosa cells stimulated with aldosterone secretagogues. Physiol. Genomics. 32 (1), 117-127.

Rossier, M.F., Capponi, A.M. 2000. Angiotensin II and calcium channels. Vitam. Horm. 60, 229-84.

Shah, B.H., Yesilkaya, A., Olivares-Reyes, J.A., Chen, H.D., Hunyady, L., Catt, K.J. 2004. Differential pathways of angiotensin II-induced extracellularly regulated kinase $1 / 2$ phosphorylation in specific cell types: role of heparin-binding epidermal growth factor. Mol. Endocrinol. 18 (8), 2035-2048.

Shah, B.H., Baukal, A.J., Chen, H.D., Shah, A.B., Catt, K.J. 2006. Mechanisms of endothelin-1-induced MAP kinase activation in adrenal glomerulosa cells. J Steroid Biochem. Mol. Biol. 102 (1-5), 79-88. 
Spät, A., Balla, T., Enyedi, P. 1981. The effect of endogenous angiotensin on the biosynthesis of aldosterone in the rat. J. Steroid Biochem. 14 (11), 1147-1152.

Spät, A. 1988. Stimulus-secretion coupling in angiotensin-stimulated adrenal glomerulosa cells. J. Steroid Biochem. 29 (4), 443-453.

Spät, A., Balla, I., Balla, T., Cragoe, E.J. Jr, Hajnóczky, G., Hunyady, L. 1989. Angiotensin II and potassium activate different calcium entry mechanisms in rat adrenal glomerulosa cells. J. Endocrinol. 122 (1), 361-370.

Spät, A., Enyedi, P., Hajnóczky, G., Hunyady, L. 1991. Generation and role of calcium signal in adrenal glomerulosa cells. Exp. Physiol. 76 (6), 859-885.

Spät, A., Hunyady, L. 2004. Control of aldosterone secretion: a model for convergence in cellular signaling pathways. Physiol. Rev. 84 (2), 489-539.

Suzuki, J., Otsuka, F., Inagaki, K., Takeda, M., Ogura, T., Makino, H. 2004. Novel action of activin and bone morphogenetic protein in regulating aldosterone production by human adrenocortical cells. Endocrinology. 145 (2), 639-649.

Szidonya, L., Süpeki, K., Karip, E., Turu, G., Várnai, P., Clark, A.J., Hunyady, L. 2007. AT1 receptor blocker-insensitive mutant AT1A angiotensin receptors reveal the presence of G protein-independent signaling in C9 cells. Biochem. Pharmacol. 73 (10), 1582-1592.

Vinson, G.P. 2004. Glomerulosa function and aldosterone synthesis in the rat. Mol Cell Endocrinol. 217 (1-2), 59-65.

Wei, H., Ahn, S., Shenoy, S.K., Karnik, S.S., Hunyady, L., Luttrell, L.M., Lefkowitz, R.J. 2003. Independent beta-arrestin 2 and $G$ protein-mediated pathways for angiotensin II activation of extracellular signal-regulated kinases 1 and 2. Proc. Natl. Acad. Sci. U S A. $100(19), 10782-10787$. 
Table 1. Real time PCR primers used for the amplifications of human (h) and rat (r) genes. Primer set for human CYP11B2 was purchased from SuperArray Biosciences (Frederick, MD). Amplicon sizes are between 109 and 190 base pairs.

\begin{tabular}{|l|l|l|l|}
\hline Gene Name & Accession & forward primer & reverse primer \\
\hline hGAPDH & ENSG00000111640 & AAGGTGAAGGTCGGAGTCAACG & GACGGTGCCATGGAATTTGC \\
\hline hNR4A1 & ENSG00000123358 & GCATGGTGAAGGAAGTTGTC & AGGGAAGTGAGGAGATTGG \\
\hline hNR4A2 & ENSG00000153234 & GGGATGGTCAAAGAAGTGGTTCG & GGTCATAGCCGGGTTGGAGTC \\
\hline rGAPDH & ENSRNOG00000004253 & CCTGCACCACCAACTGCTTAG & CAGTCTTCTGAGTGGCAGTGATG \\
\hline rNR4A1 & ENSRNOG00000007607 & AGGGACGTGAGGAGATTGG & GACGTGAGGAGATTGGTAGG \\
\hline rNR4A2 & ENSRNOG00000005600 & TCACTCGGCTGAAGCCATGC & TCAGTGTTGGTGAGGTCCATGC \\
\hline rCYP11B2 & ENSRNOG00000030111 & GTCATCTCTGAGTATGCCAACAGA & GCAGTGAGCTCCATAGAGTTGG \\
\hline
\end{tabular}

\section{Figure legends}

Fig. 1. Dose-response curves of Ang II ( $n=3-6)$. Expression of NR4A1 and NR4A2 genes in H295R cells (Panels A-B) and rat glomerulosa cells (Panels C-D) stimulated by Ang II for 1 hour (black dots) or 6 hours (white dots). Standardization was made against $\mathrm{GAPDH}$ control gene. Mean \pm SEM values are shown.

Fig. 2. Time-dependent effect of Ang II on the expression of genes in human and rat adrenocortical cells. H295R cells (Panels A-C, n=4) and rat glomerulosa cells (Panels D$\mathrm{F}, \mathrm{n}=3)$ were stimulated with Ang II $(1 \mu \mathrm{M})$. Standardization was made against GAPDH control gene. Mean \pm SEM values are shown.

Fig. 3. Localization of Nurr1 in human and rat adrenocortical cells visualized by immunofluorescence. H295R and rat glomerulosa cells were stimulated for 24 hours with $1 \mu \mathrm{M}$ Ang II, which stimulation was repeated after 12 hours. Immunostaining was performed and rhodamine fluorescence was detected by confocal microscopy (Panel A). Images were analyzed with Zeiss LSM Image Browser and ImageJ softwares. Cell nucleus/plasma fluorescence ratio was analyzed and compared between control and Ang II-treated cells (panel B). Several cells of each of 3-4 images for each treatments of 2-2 separate experiments were analyzed. Mean \pm SEM values are shown. ${ }^{*} \mathrm{p}<0.05$ compared to control.

Fig. 4. Localization of NGFIB in human and rat adrenocortical cells visualized by immunofluorescence. H295R and rat glomerulosa cells were stimulated with $2 \mu \mathrm{M}$ Ang II for 24 hours. Immunostaining was performed and rhodamine fluorescence was detected by confocal microscopy (Panel A). Images were analyzed with Zeiss LSM Image Browser and ImageJ softwares. Cell nucleus/plasma fluorescence ratio was analyzed and compared between control and Ang II-treated cells (Panel B). Several cells of each of 3-4 images for each treatments of 3-3 separate experiments were analyzed. Mean \pm SEM values are shown. $* \mathrm{p}<0.05$ compared to control. 
Fig. 5. Ang II-induced signaling mechanisms involved in the expression of NR4A1 (NGFIB) and NR4A2 (Nurr1) genes in human and rat adrenocortical cells. H295R (panels $\mathrm{A}, \mathrm{B}, \mathrm{n}=4$ ) and rat glomerulosa cells (panels $\mathrm{C}, \mathrm{D}, \mathrm{n}=3-5$ ) were treated with MEK inhibitor (PD98059, 20 $\mu \mathrm{M})$, PKC inhibitor (BIM1, $3 \mu \mathrm{M}$ ) and calmodulin kinase inhibitor $(\mathrm{KN} 93,10 \mu \mathrm{M})$ half hour prior to 1-hour Ang II $(100 \mathrm{nM})$ stimulation. Mean $\pm \mathrm{SEM}$ values are shown. Standardization was made against GAPDH control gene. * statistically significant interaction $(p<0.05)$ of the inhibitor with the Ang II response.

Fig. 6. Ang II-induced signaling mechanisms involved in the expression of NR4A1 (NGFIB, panel A), NR4A2 (Nurr1, panel B) and CYP11B2 (panel C) genes in H295R cells $(\mathrm{n}=4-8)$. Cells were treated with MEK inhibitor (PD98059, 20 $\mu \mathrm{M})$, PKC inhibitor $(\mathrm{BIM} 1,3 \mu \mathrm{M})$ and calmodulin kinase inhibitor $(\mathrm{KN} 93,10 \mu \mathrm{M})$ half hour prior to 6-hour Ang II $(1 \mu \mathrm{M})$ stimulation. Mean \pm SEM values are shown. Standardization was made against GAPDH control gene. \# statistically significant $(\mathrm{p}<0.05)$ compared to control, $\uparrow$ statistically significantly $(\mathrm{p}<0.05)$ reduced stimulation compared to the Ang IIstimulated level in the absence of inhibitor (one-way ANOVA), * statistically significantly $(\mathrm{p}<0.05)$ reduced stimulation compared to the Ang II-stimulated level in the absence of inhibitor (one-way ANOVA) and statistically significant $(\mathrm{p}<0.05)$ interaction of the inhibitor with the Ang II response (two-way ANOVA).

Fig. 7. Ang II-induced signaling mechanisms involved in the expression of NR4A1 (NGFIB, panel A) and CYP11B2 (panel B) genes in rat glomerulosa cells $(\mathrm{n}=4-5)$. Cells were treated with MEK inhibitor (PD98059, 20 $\mu \mathrm{M})$, PKC inhibitor (BIM1, $3 \mu \mathrm{M})$ and calmodulin kinase inhibitor $(\mathrm{KN} 93,10 \mu \mathrm{M})$ half hour prior to 6-hour Ang II $(1 \mu \mathrm{M})$ stimulation. Mean \pm SEM values are shown. Standardization was made against GAPDH control gene. * statistically significant interaction $(\mathrm{p}<0.05)$ of the inhibitor with the Ang II response.

Fig. 8. Effect of $\mathrm{Sar}^{1}-\mathrm{Ile}^{4}-\mathrm{Ile}{ }^{8}$-Ang II (SII) on the expression of NR4A1, NR4A2 and CYP11B2 genes in human and rat adrenocortical cells. H295R cells (panel A, n=4) and rat glomerulosa cells (panel B, $\mathrm{n}=3$ ) were treated with $1 \mu \mathrm{M}$ Ang II and $30 \mu \mathrm{M}$ SII for 6 hours in order to investigate Ang II-induced G protein-independent effects. Mean \pm SEM values are shown. Standardization was made against GAPDH control gene. ${ }^{*} \mathrm{p}<0.05$ compared to control. 
Figure 1

A

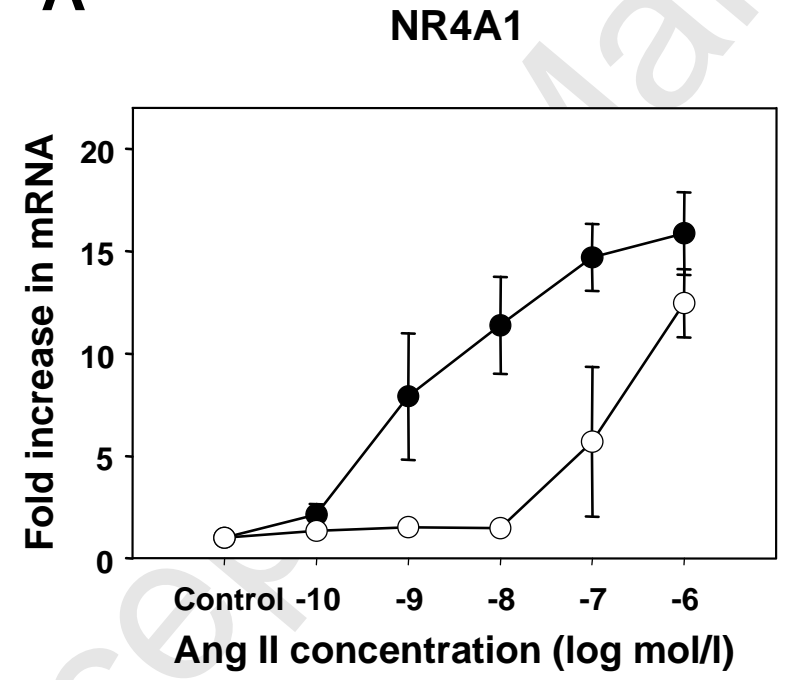

C

NR4A1

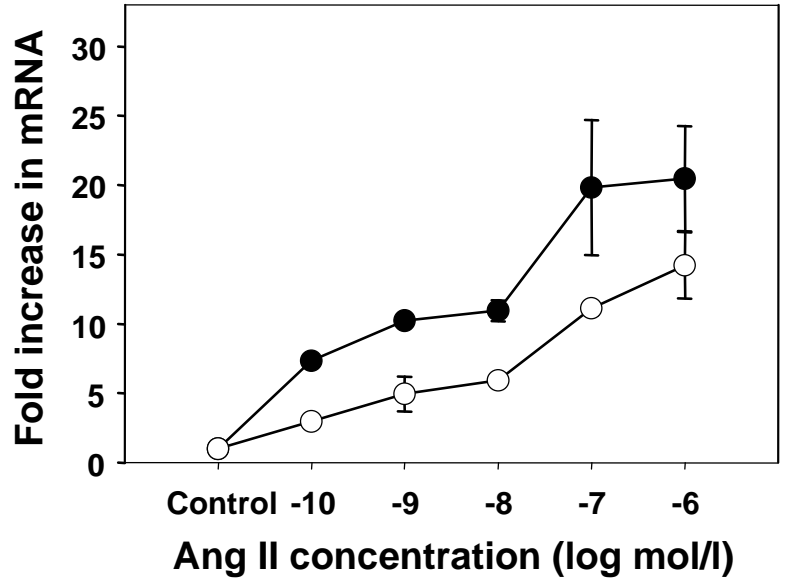

B

NR4A2

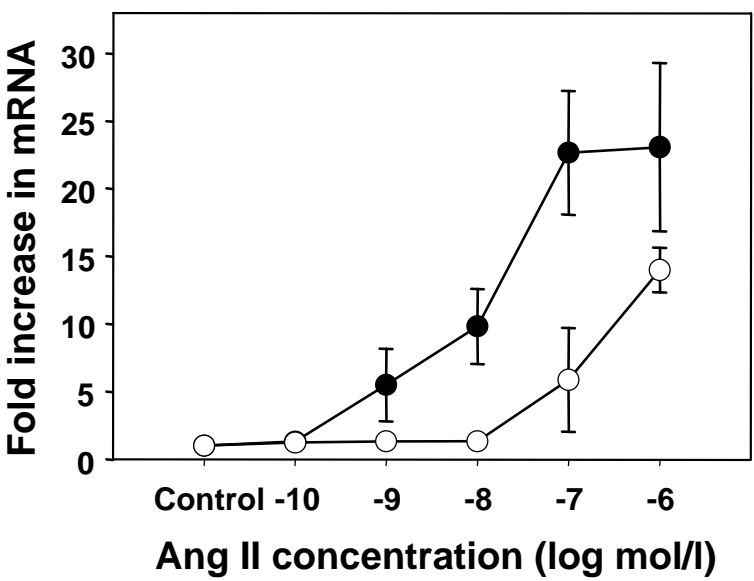

D

NR4A2

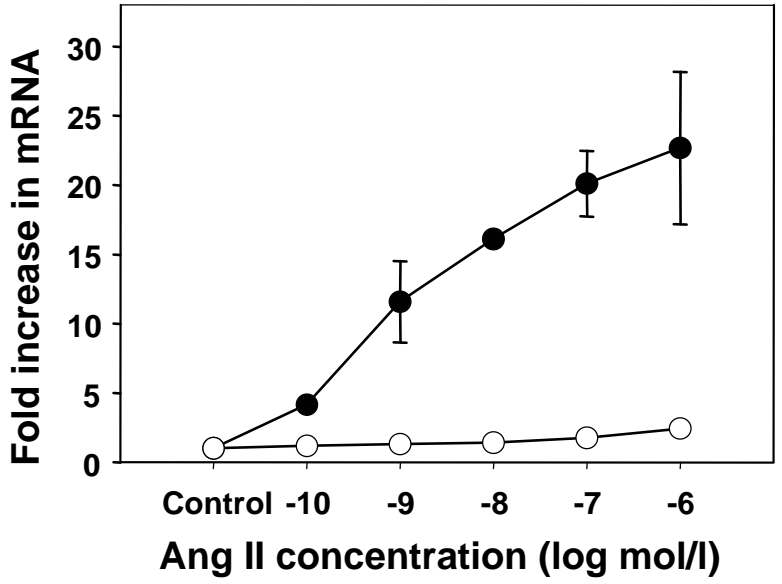

H295R

rat 
Figure 2

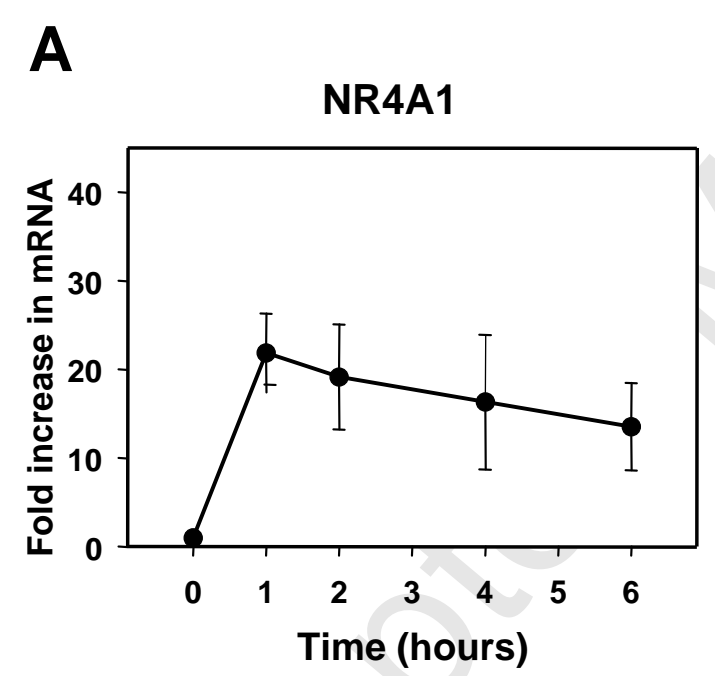

D

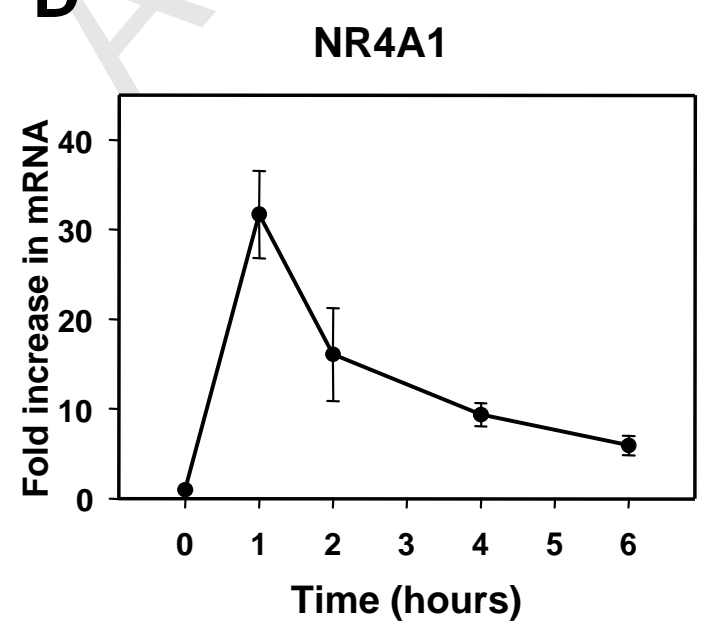

B

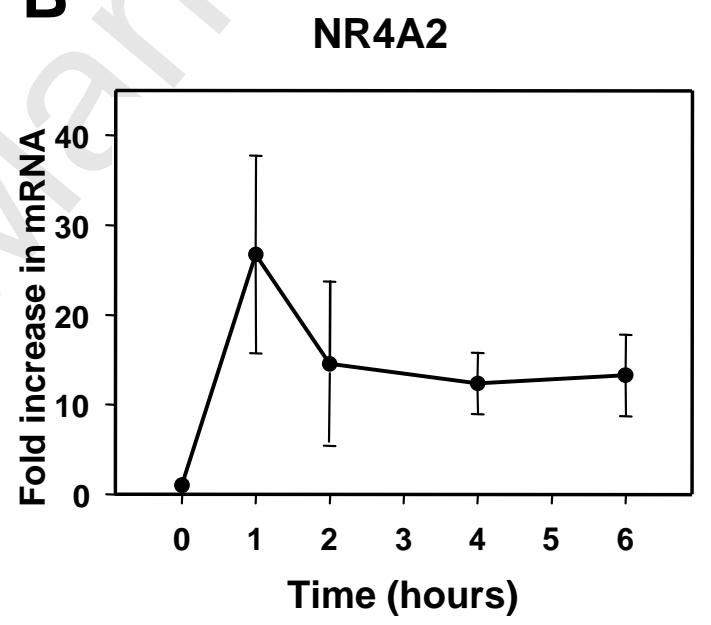

E

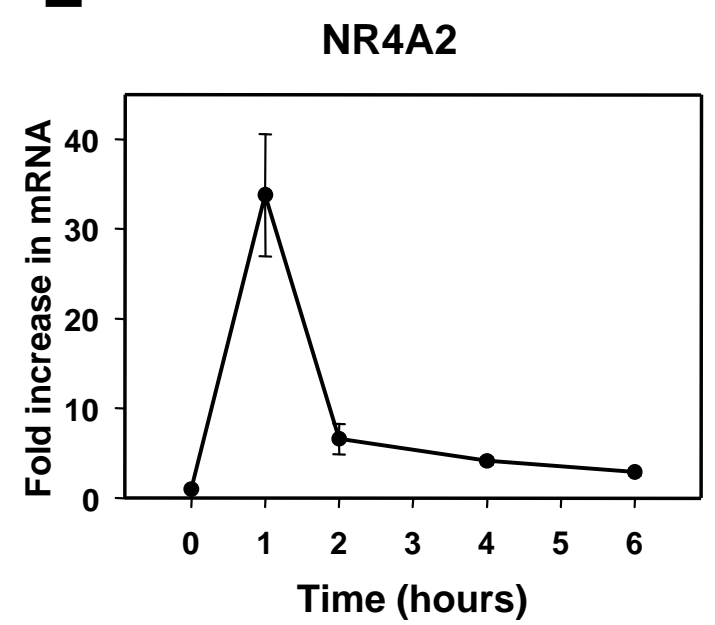

C

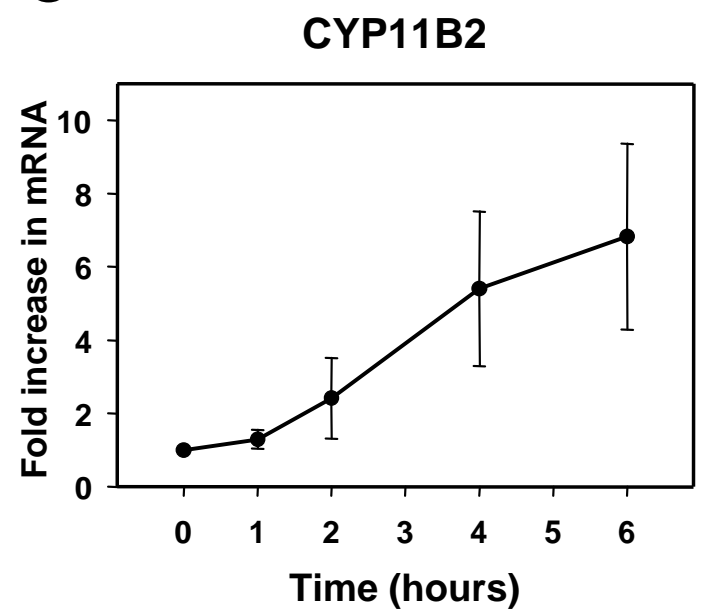

F

rat

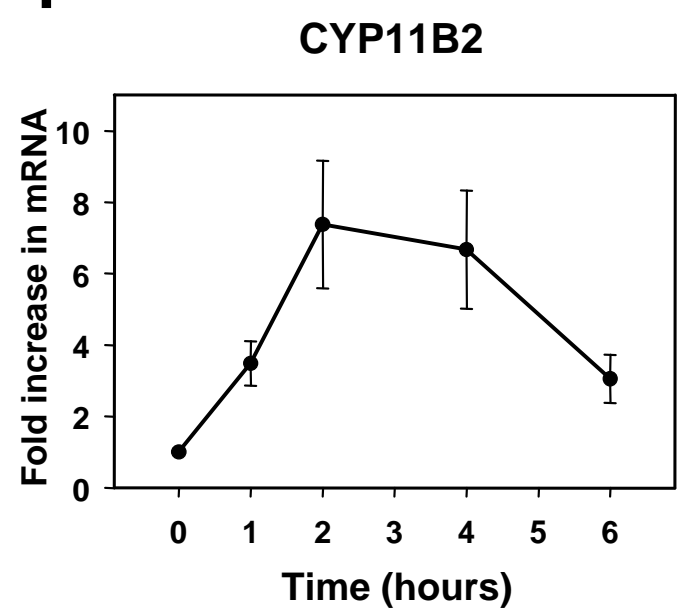


Figure3

A

\section{H295R}

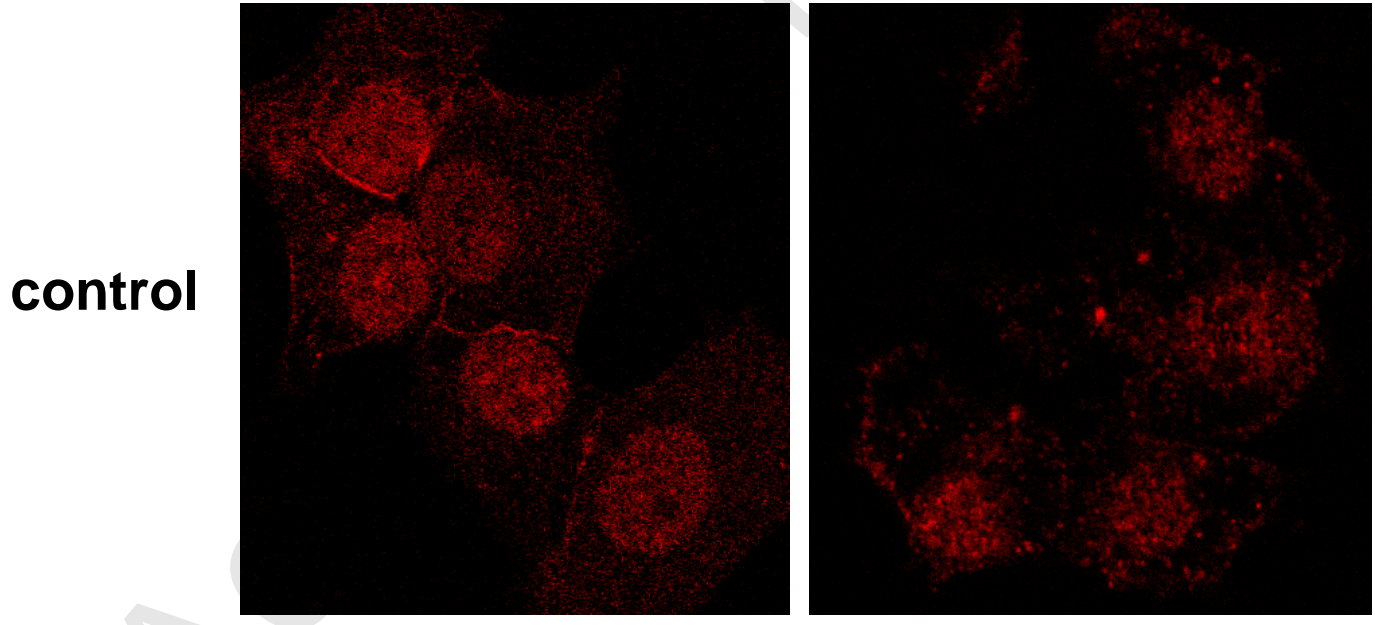

Ang II
B

\section{rat glomerulosa}

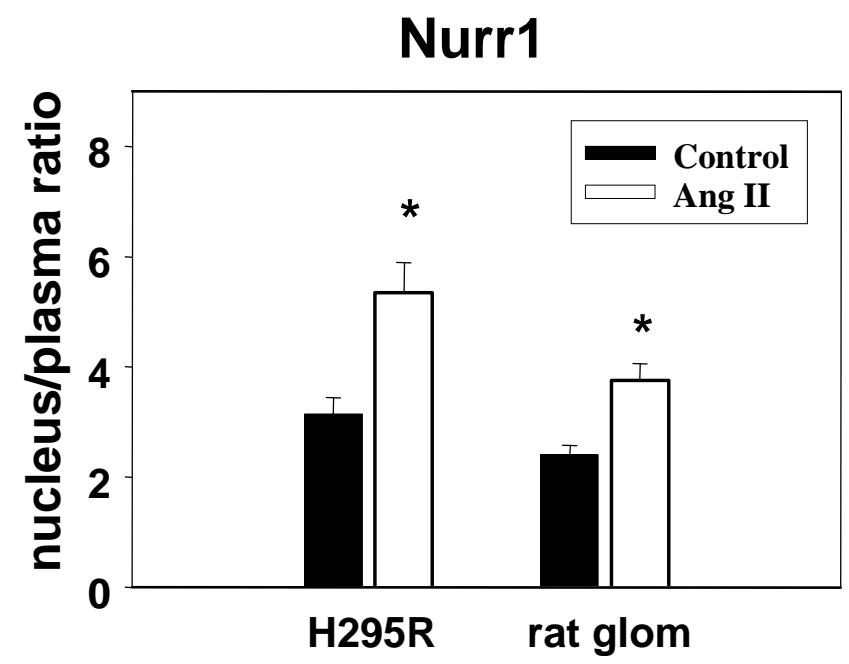


Figure 4

A

\section{H295R}

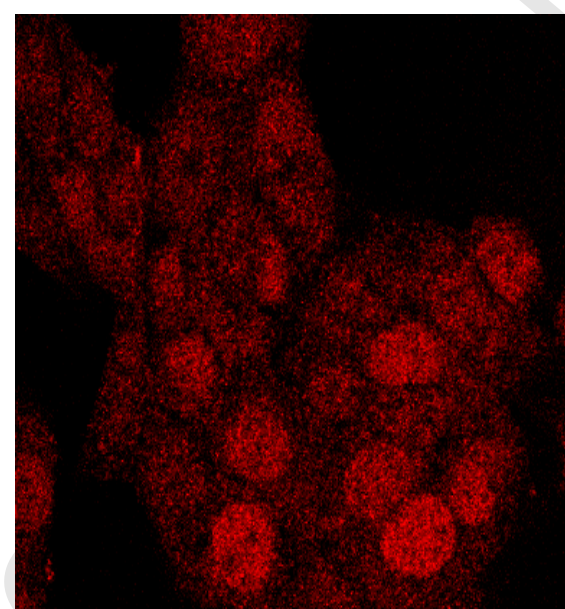

control

Ang II

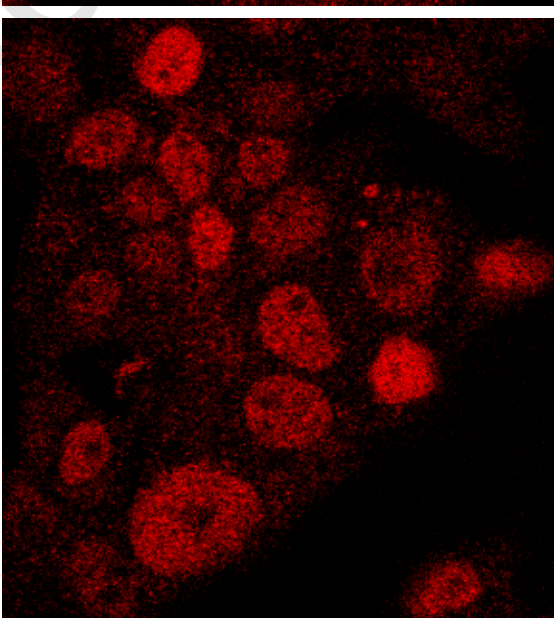

\section{rat glomerulosa}

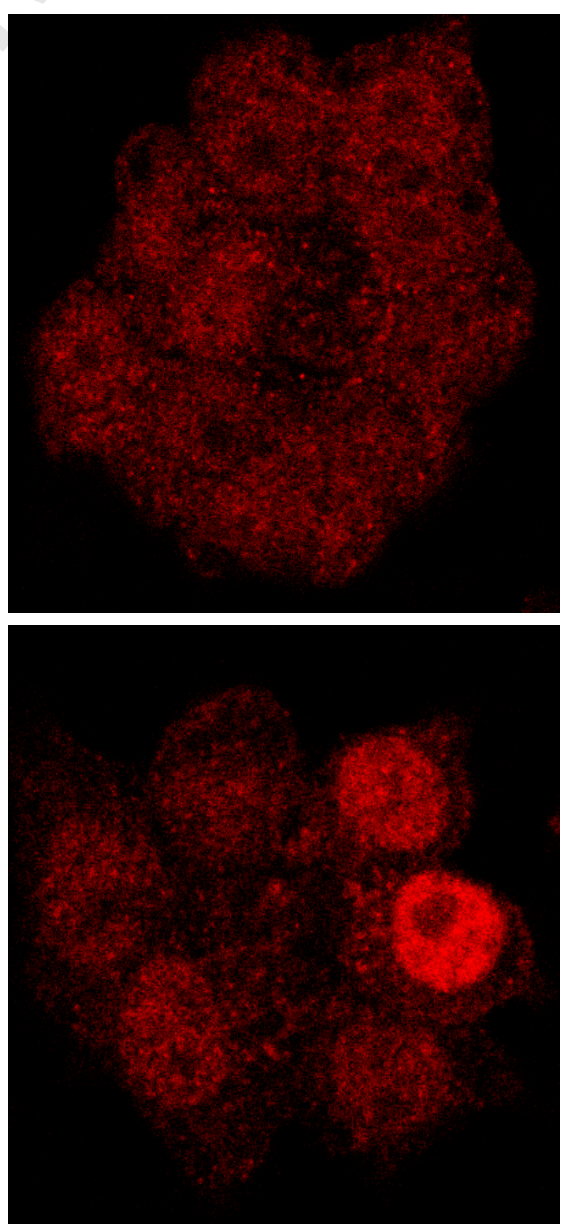

B

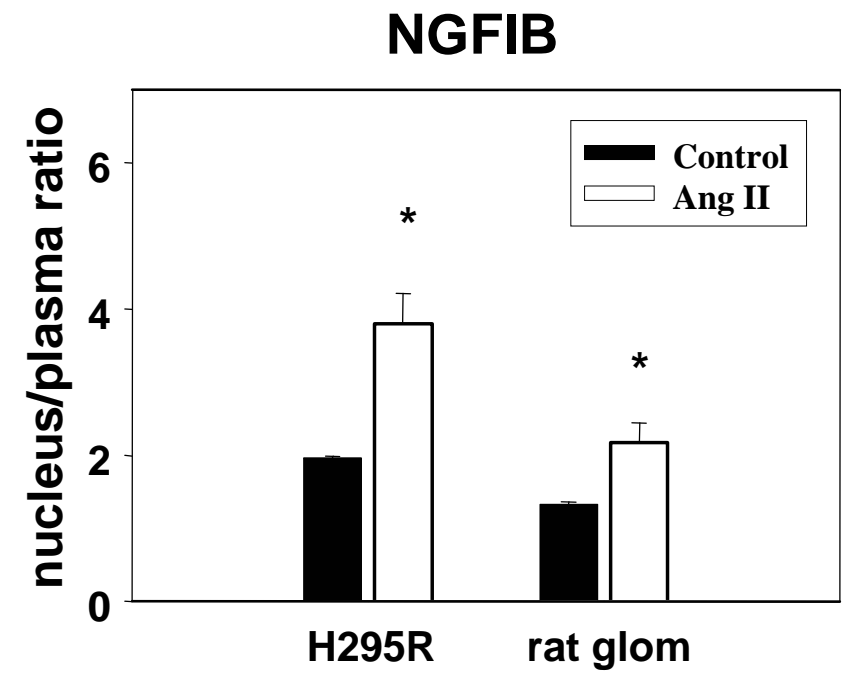


Figure 5
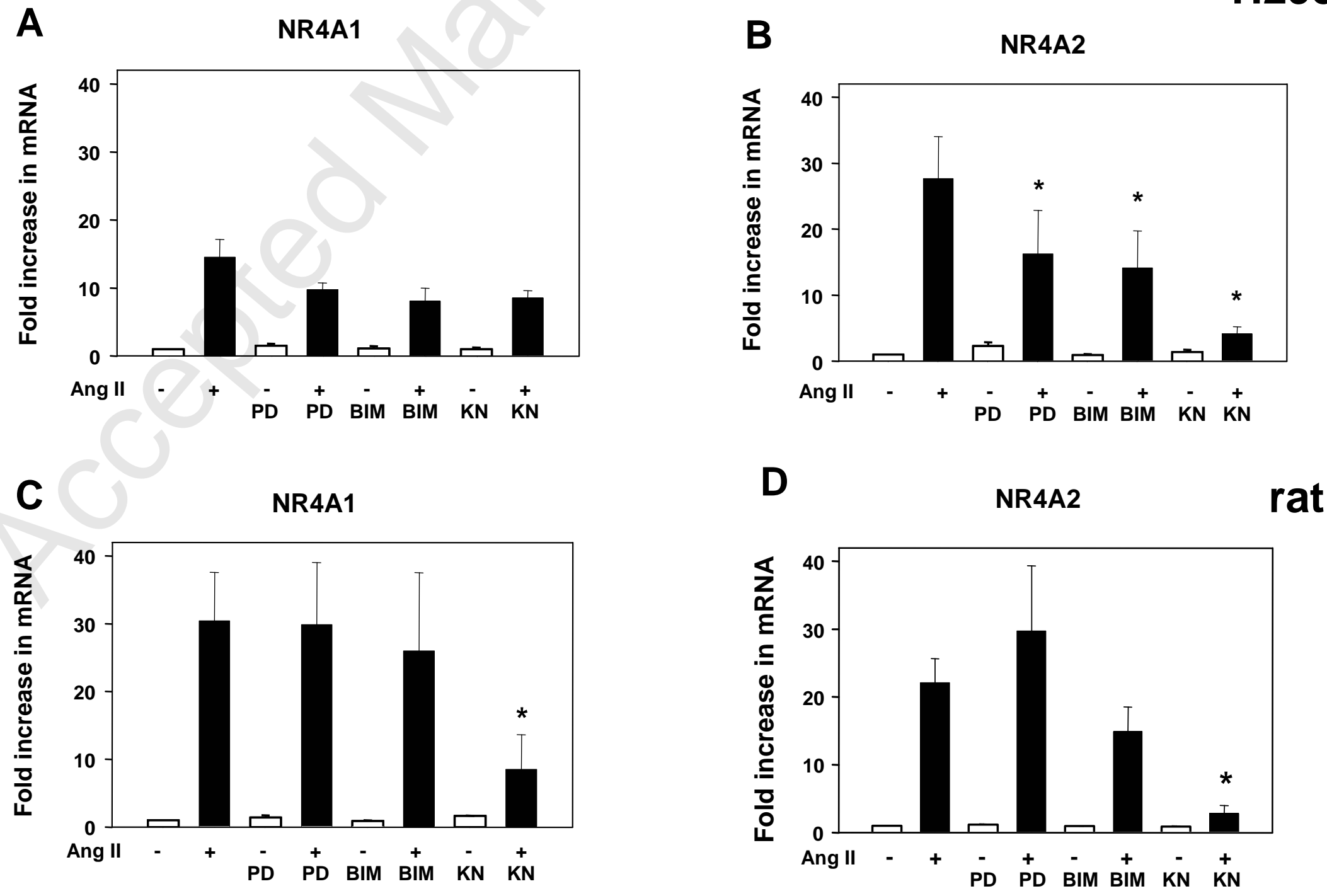
Figure 6

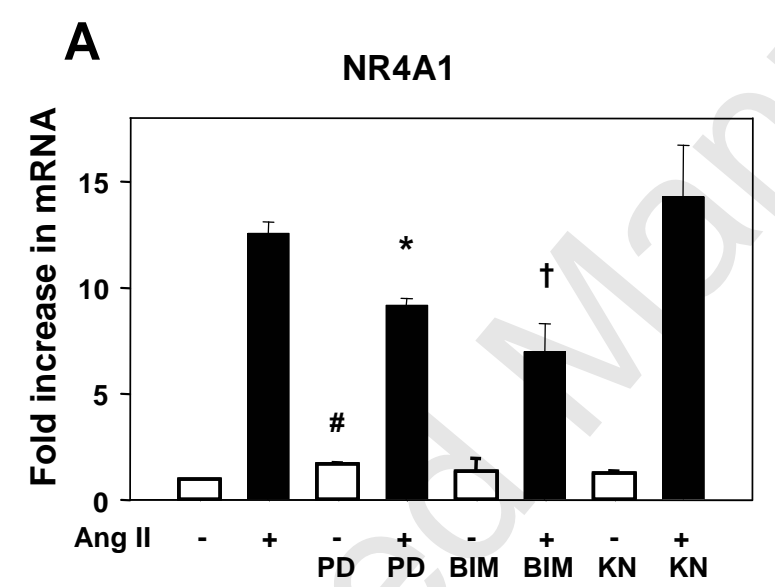

B

NR4A2
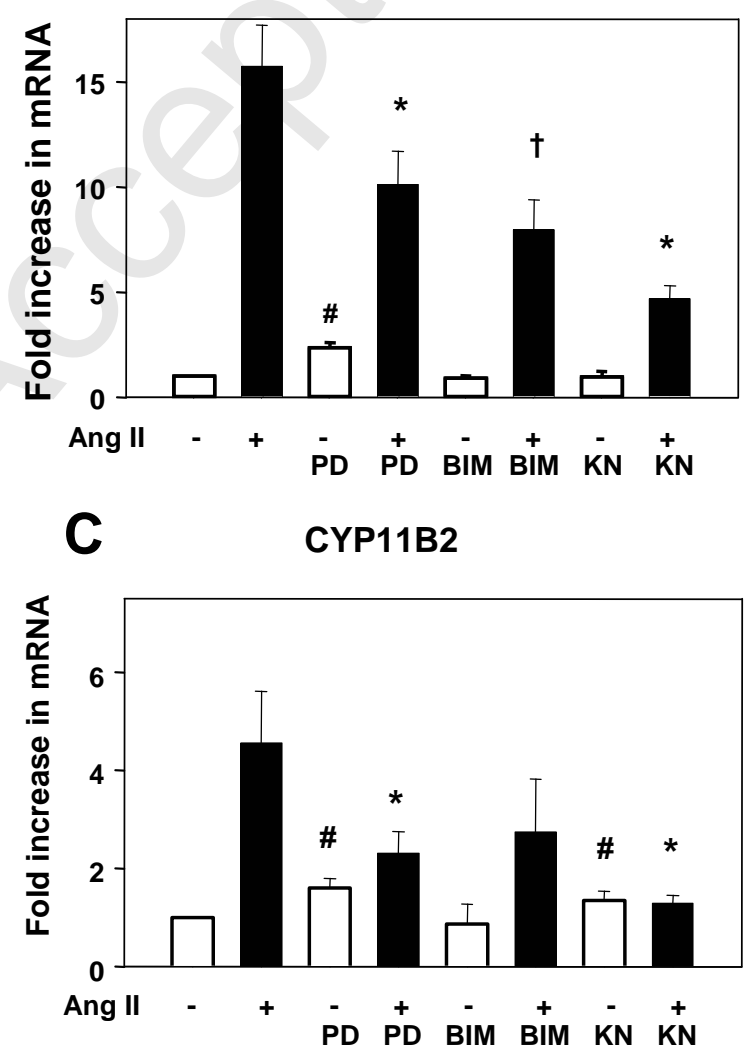
Figure 7
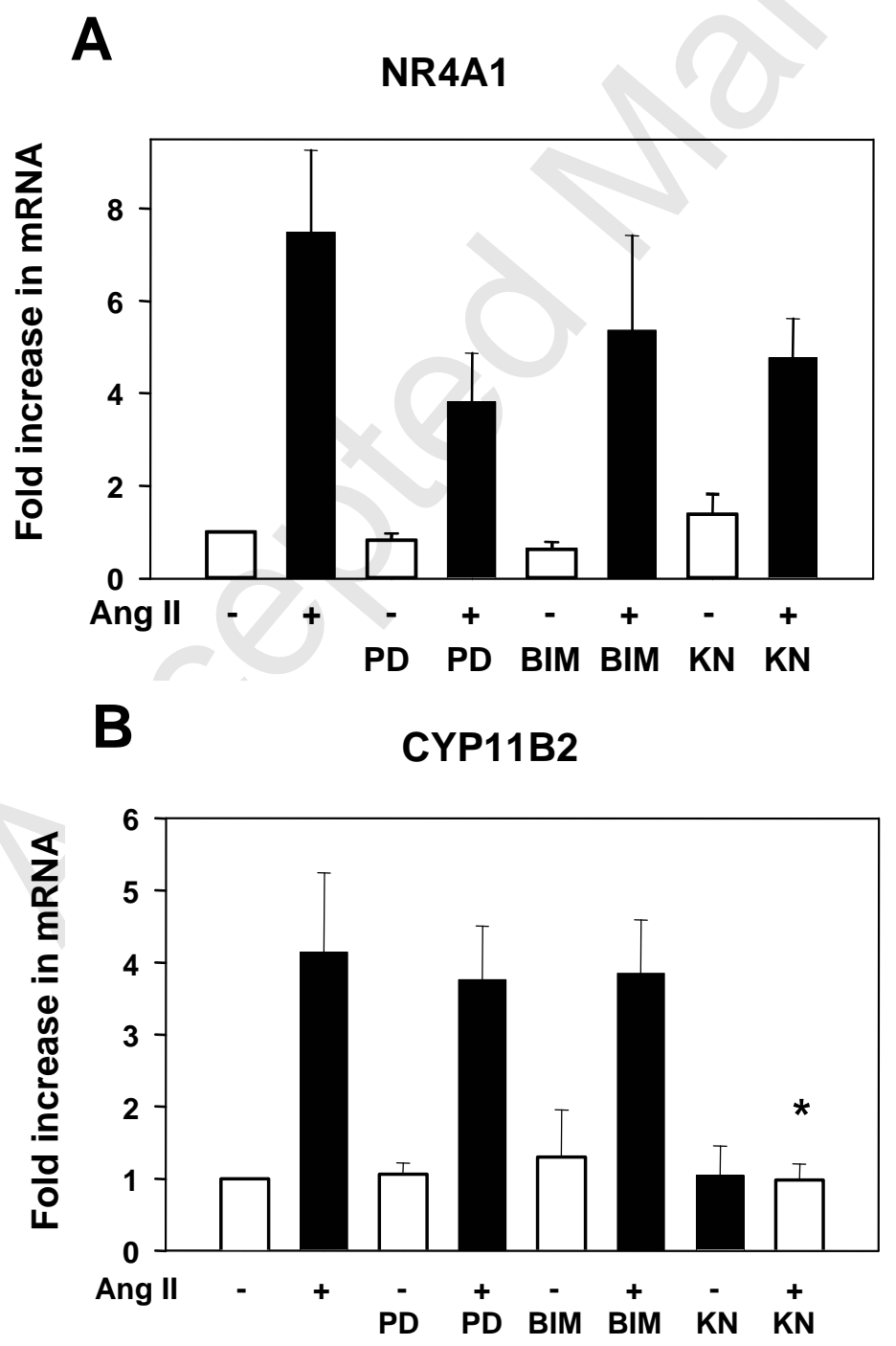
Figure 8

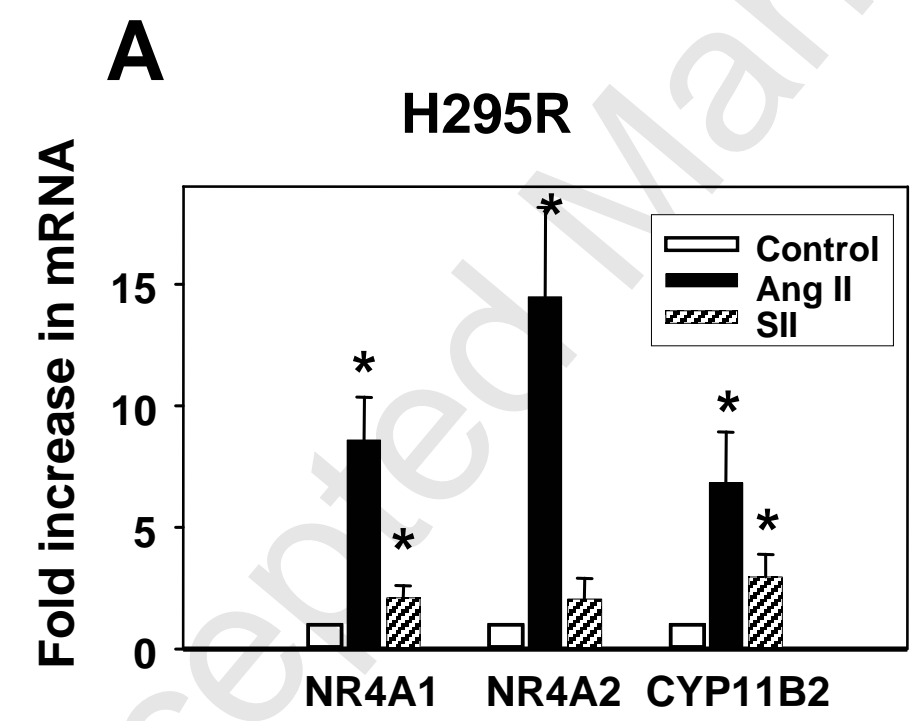

\section{B}

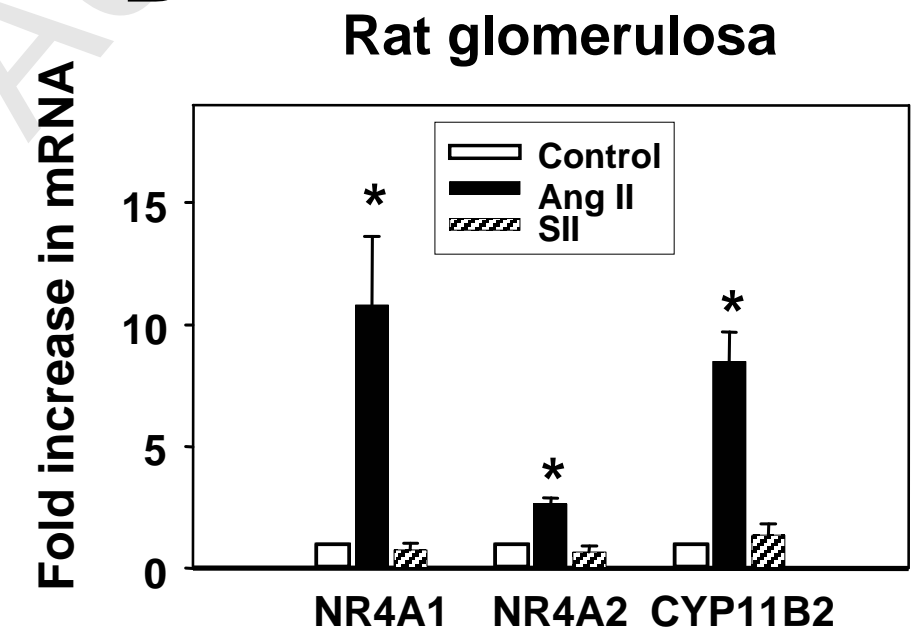

